\title{
Evidence of microplastic translocation in wild-caught fish and implications for microplastic accumulation dynamics in food webs
}

Hayley K. McIlwraith, Joel Kim, Paul Helm, Satyendra P. Bhavsar, Jeremy S. Metzger, Chelsea M. Rochman

Methods

\section{Table of Contents}

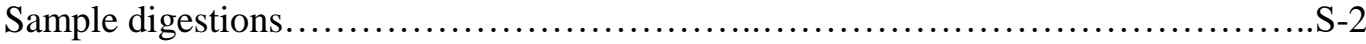

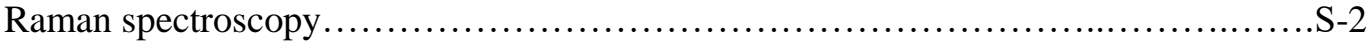

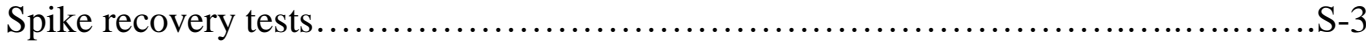

Discussion

Microplastic abundance differs among species but not habitat.....................

Patterns relevant to effects of microplastic translocation...........................

Figures

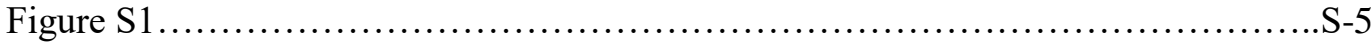

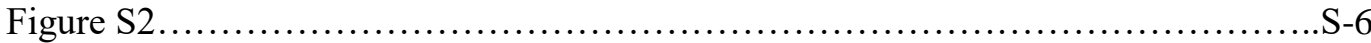

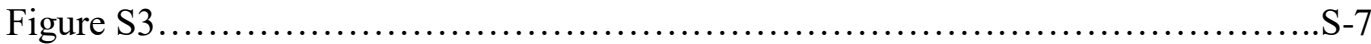

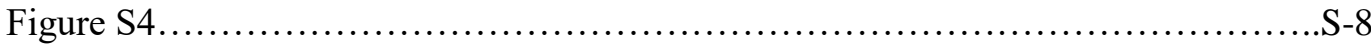

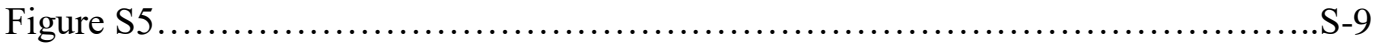

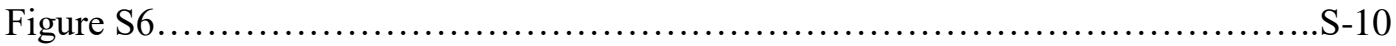

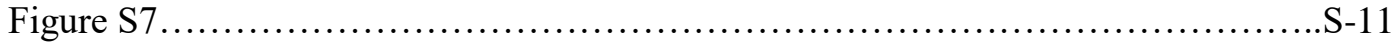

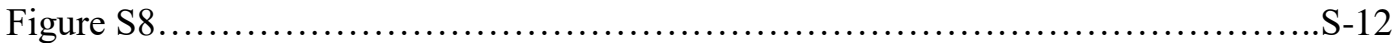

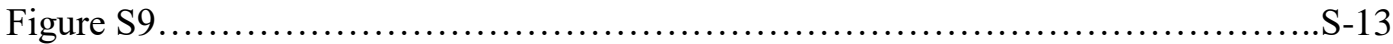

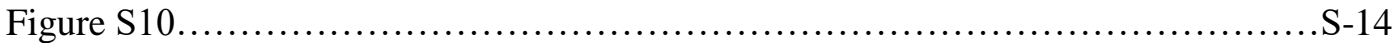

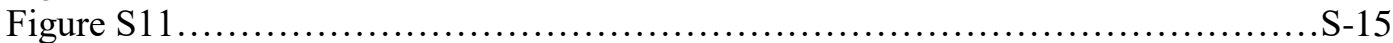

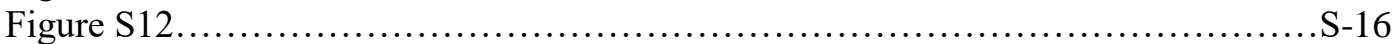

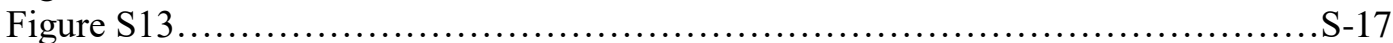

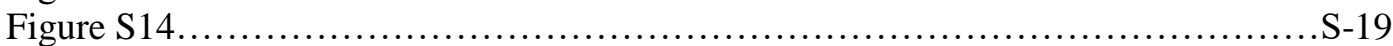

Tables

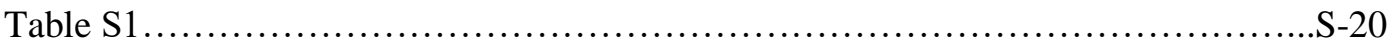

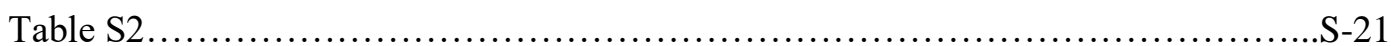

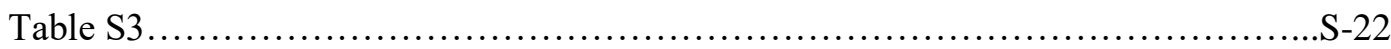

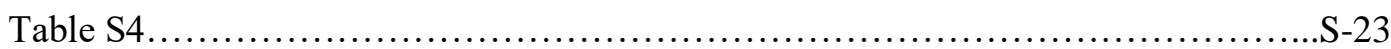

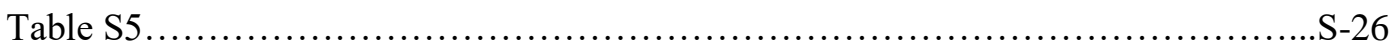

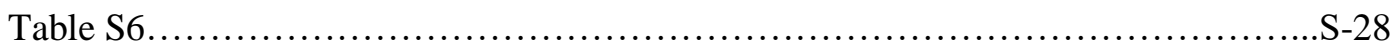

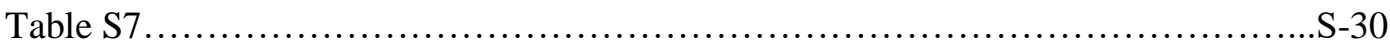

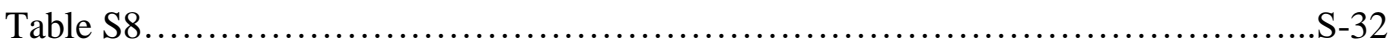

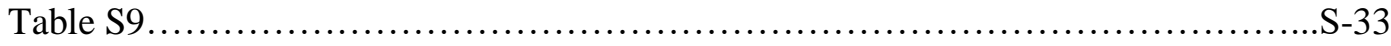

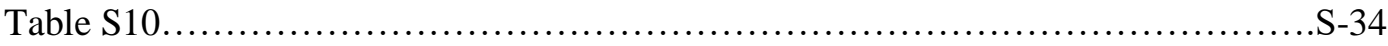

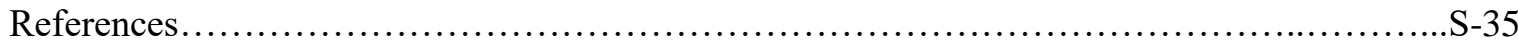


Sample digestions. For the detergent soak, samples were submerged in a 1:2 detergent:RO (reverse osmosis) water mixture using Decon Contrad 70 (Thermo Fisher Scientific) and left for 24 hours. If samples were still not fully digested or had excessive fatty residues, samples went through the wet peroxide oxidation phase. In this treatment, $20 \mathrm{~mL}$ of $\mathrm{Fe}(\mathrm{II}) \mathrm{SO}_{4}$ catalyst was initially added to the samples. A $20 \mathrm{~mL}$ aliquot of $35 \% \mathrm{H}_{2} \mathrm{O}_{2}$ was then added and the reaction was carefully monitored to ensure that the temperature did not exceed 60 ${ }^{\circ} \mathrm{C}$. A total of five aliquots were added. Based on tests done on different microplastic types and digestion methods, temperatures $<60{ }^{\circ} \mathrm{C}$ have been suggested for tissue digestions to minimize losses of microplastics ${ }^{1}$. Given that the Fenton reaction is an exothermic reaction, an ice bath was available to cool the reaction, as required, to prevent high temperature degradation of any plastic particles that may have been present.

Detergent was added to the sample containers and rinsed out three times with RO water to ensure removal of any remaining sticky fatty residues. A copious amount of RO water was then used to rinse out the containers to ensure complete transfer. Sieved contents were then transferred to clean, labelled containers using RO water for sorting and quantification.

Raman Spectroscopy. We used a filter ranging from $0.1 \%$ to $100 \%$, gratings of 600 or 1200 grooves/mm, up to $8 \mathrm{~s}$ for acquisition time, 2, 4, 6, or 8 number of accumulations, a confocal hole diameter of $100 \mathrm{~mm}$ or $300 \mathrm{~mm}$, and a confocal slit width of 50 or $100 \mathrm{~mm}$. When acquiring spectra, parameters were optimized to inhibit poor resolution, fluorescence, and other issues. This resulted in particles having a different suite of parameters (for example, the $785 \mathrm{~nm}$ would provide a better spectrum for darkly colored particles). The spectral library used was BioRad KnowItAll Raman Spectral Library and the Spectral Library of Plastic Particles, - Environmental (SLoPP and SLoPP-E $)^{2}$. A spectral match generally fell between $80 \%$ and $98 \%$, with a few exceptions made based on judgement of spectral features.

Suspected microplastics were assigned material categories based on spectroscopy database matches. Confirmed 'Plastic' includes all common plastic polymers (e.g., polyethylene (PE), polypropylene (PP), polyamide (PA), polyethylene terephthalate (PET), polyethylene imine (PEI), polymethyl methacrylate (PMMA), acrylonitrile butadiene styrene (ABS), and ethylene propylene diene monomer rubber (EPDM rubber)). 'Anthropogenic synthetic' includes particles where an additive indicating synthetic origin was identified but the underlying polymer 
could not be identified (e.g., plasticizers). 'Anthropogenic cellulosic' are particles containing cellulose and pigments or additives indicating anthropogenic origin. 'Anthropogenic unknown' includes particles where an anthropogenic dye is detected but the underlying material is not, and it is unclear whether the underlying particle is plastic or not. 'Unknown cellulosic' includes particles containing cellulose but their origin could not be determined. Particles in this category may not be anthropogenic. 'Unknown' particles could not be identified due to photodegradation, fluorescence or a lack of Raman signal, and thus also may not be anthropogenic. 'Natural' categories include inorganic materials, such as minerals, and are not anthropogenic. Reported particle numbers were not adjusted for results of spectroscopy.

Spike recovery tests. We performed spike recovery tests in the laboratory to assess recovery rates using the same methods as described for tissue samples. Using five different microplastics (red fibers, white fragments, purple spheres, white spheres, and red fragments; $\mathrm{n}=$ 10) ranging in size from $125 \mu \mathrm{m}$ to $333 \mu \mathrm{m}$, we spiked $4 \mathrm{~g}$ of Rainbow Trout and White Sucker GI tract tissues. To represent a sample high in fat, we spiked salmon oil tablets (4 x $1000 \mathrm{mg})$ with the same microplastics mixture. All spiked samples had recoveries > 85\% (Table S2).

Microplastic abundance differs among species but not habitat. The species included in this study are generalists with similar diets, consisting of insects, crayfish, and small fishes ${ }^{3}$. Thus, observed differences are more likely attributable to body size, trophic position, or stomach and intestine complexity ${ }^{4,5}$. Northern Pike and Largemouth Bass, both of which occupy the highest trophic fraction in this study, had significantly more particles than Yellow Perch. Yellow Perch is at a lower trophic level, but also has a smaller body mass and length, which likely contributes to these differences (Table S1). Northern Pike from an urban prairie creek also had the highest abundance of microplastics compared to four other species (consisting of Five-Spine Stickleback, Emerald Shiner, Fathead Minnow, and White Sucker), which the researchers attributed to the trophic transfer of microplastics from smaller species ${ }^{6}$. Although there was a positive trend in particle abundance with trophic position in this study, it was weak and statistically non-significant (Fig. 3b).

There is conflicting evidence examining the differences in microplastic quantity between habitat types. Similar to our findings, pelagic and demersal fish from the English Channel 
showed no significant difference of microplastics in GI tracts ${ }^{7}$. In contrast, there have been observations of higher microplastic loads in demersal species compared to pelagic species, possibly due to higher microplastic concentrations in sediment ${ }^{8,9}$. For Lake Simcoe, the level of microplastic contamination is low in both water and sediment, which may contribute to the lack of difference in habitat observed here ${ }^{10}$. Another important distinction in this study is that benthopelagic and demersal fish species were studied, rather than pelagic and demersal species. Benthopelagic species tend to spend time at the bottom but forage higher up in the water column, while demersal species remain at the bottom to forage ${ }^{11}$. This overlap between habitats might explain why a clear difference between them was not observed in this study.

Patterns relevant to effects of microplastic translocation. Microplastics have known negative effects, such as inducing inflammation, oxidative stress, changes to gene expression, and reduced growth and feeding ${ }^{12-17}$. Because of this, a reduction in body condition with increasing microplastic load was expected, as seen in Norway lobster (Nephrops norvegicus $)^{18}$. Only one individual from our study did not contain any suspected microplastic particles. A comparison between individuals with vs. without plastic may yield a different outcome. Still, what the presence of microplastics in tissues means for a population and for human health remains unclear. While we did not observe a relationship with body condition, other indicators of fish health may have been affected, such as changes in behavioural responses and adverse effects on reproduction ${ }^{19,20}$. The high concentration of microplastics in sportfish raises many questions about the long-term effects on food security and food safety ${ }^{21}$. Overall, future studies should test the effects of microplastics at the whole-organism level, and eventually at the population level, to evaluate their impacts. 

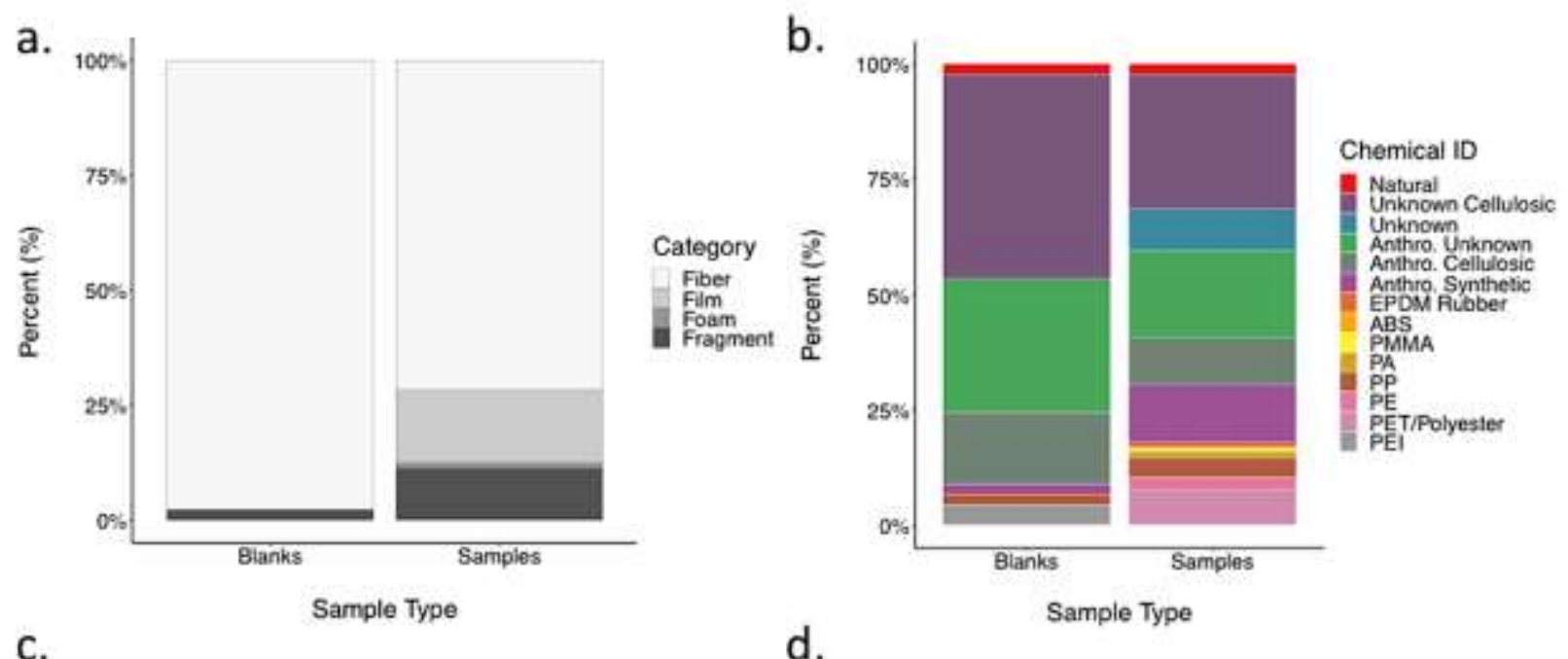

C.
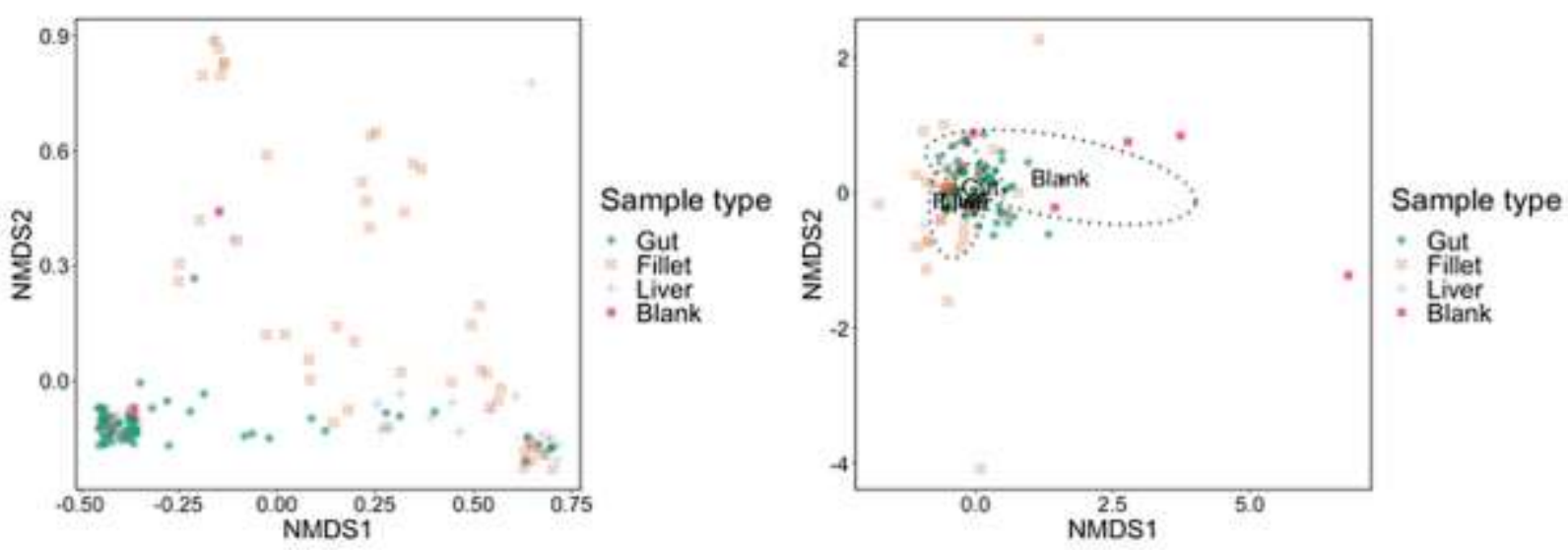

Figure S1. Suspected microplastic morphology and chemical ID assemblages in blank samples and fish samples. (a) Relative abundance of suspected microplastic morphologies in blank samples and fish samples (across all tissues); (b) Relative abundance of suspected microplastic chemical IDs based on Raman spectroscopy in blank samples and fish samples (across all tissues); (c) nMDS analysis of particle morphology assemblages in blank samples and fish samples, grouped by sample type. Stress value $=0.060$; (d) nMDS analysis of chemical ID assemblages in blank samples and fish samples, grouped by sample type. Stress value $=0.10$. nMDS analysis used Euclidean distance and 999 permutations . 
a.

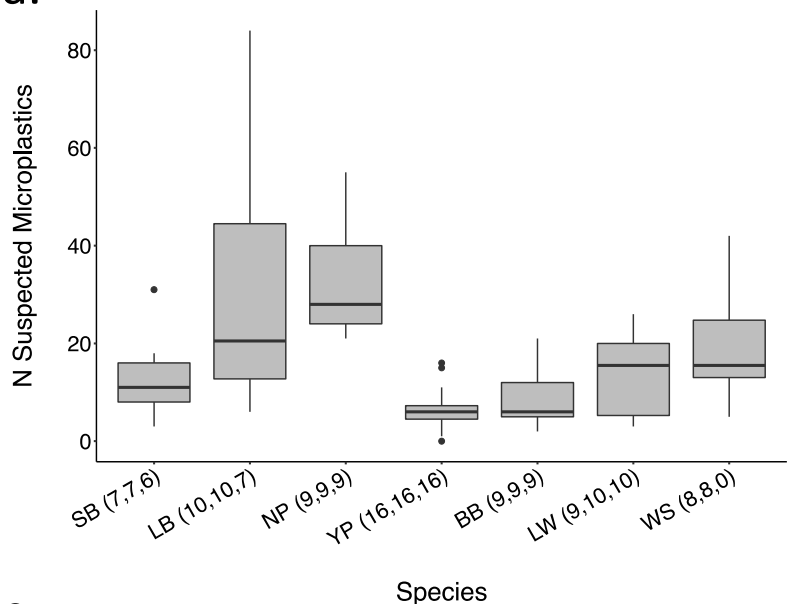

C.

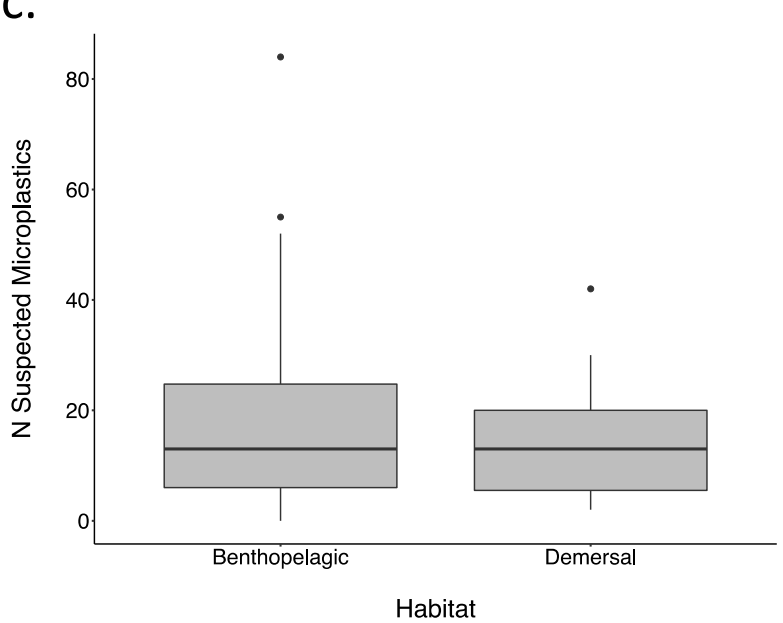

b.

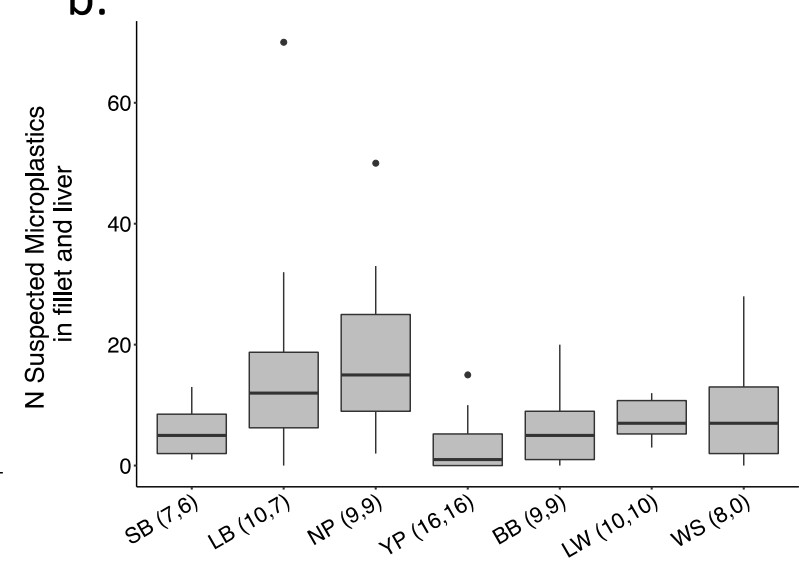

d.

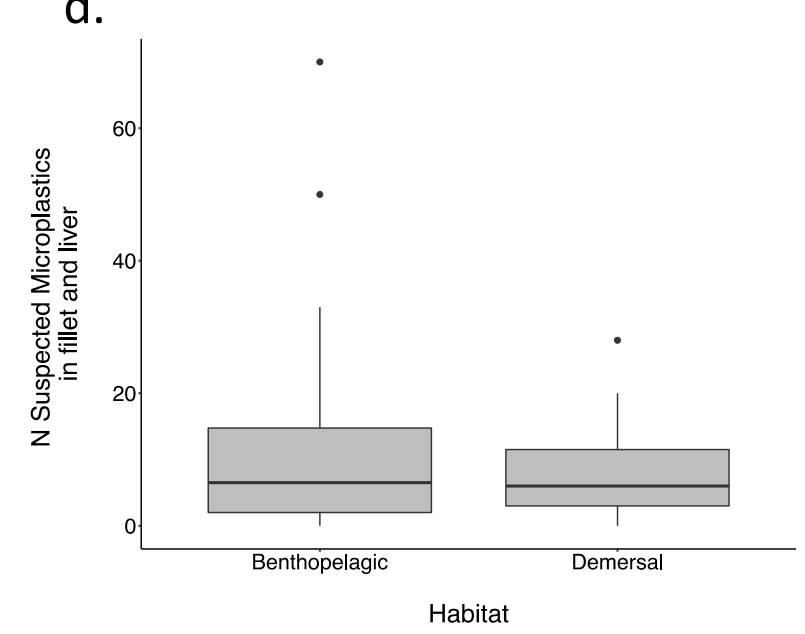

Figure S2. Number (N) of suspected microplastics in fish samples. (a) Total number of suspected microplastics (across all examined tissues) for each species. Sample sizes of each tissue (gut, fillet, liver) are indicated in brackets on the x-axis for Smallmouth Bass (SB), Largemouth Bass (LB), Northern Pike (NP), Yellow Perch (YP), Brown Bullhead (BB), Lake Whitefish (LW), and White Sucker (WS); (b) Number of suspected microplastics in the fillet and liver tissues for each species. Sample sizes are indicated in brackets on the x-axis for all species; (c) Total number of suspected microplastics (across all examined tissues) for each habitat type; (d) Number of suspected microplastics in the fillet and liver tissues for each habitat type. 
a.

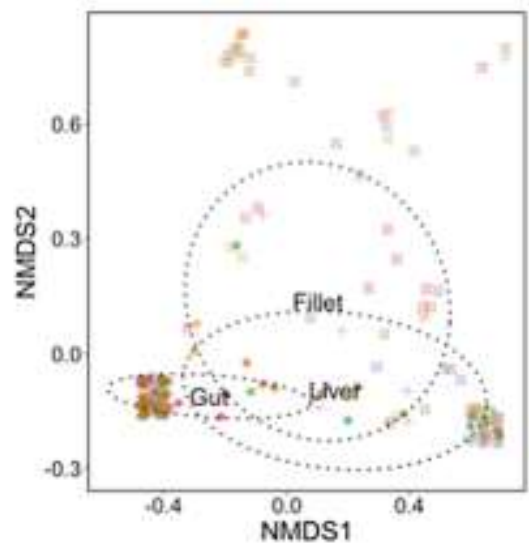

b.

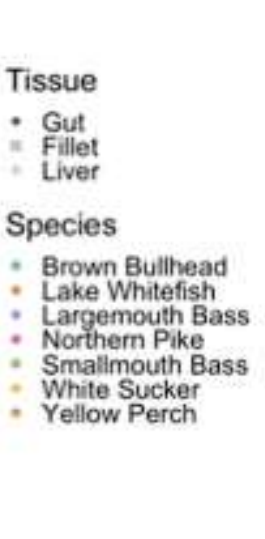

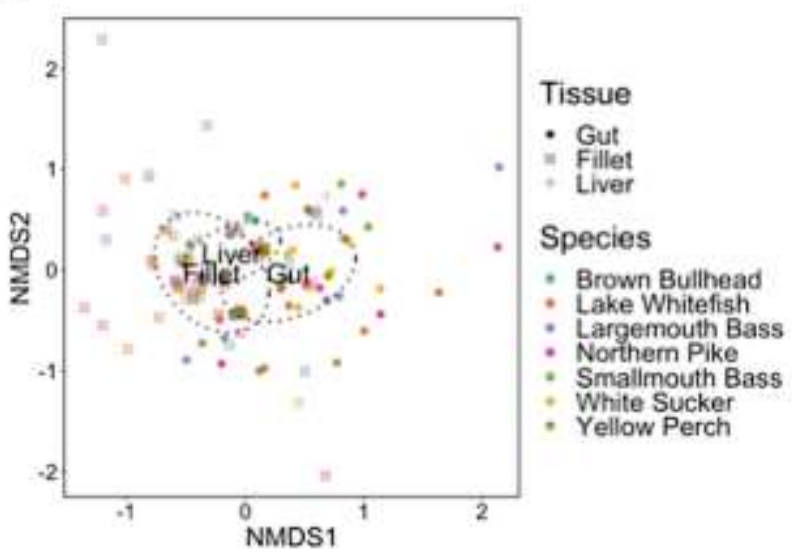

Figure S3. nMDS analysis of suspected microplastic assemblages in fish samples, grouped by tissue and species, using Euclidean distance and 999 permutations. (a) Suspected microplastic morphology assemblages. Stress value $=0.068$; (b) Suspected microplastic chemical ID assemblages. Particles were subsampled and identified using Raman spectroscopy. Stress value $=0.15$. 

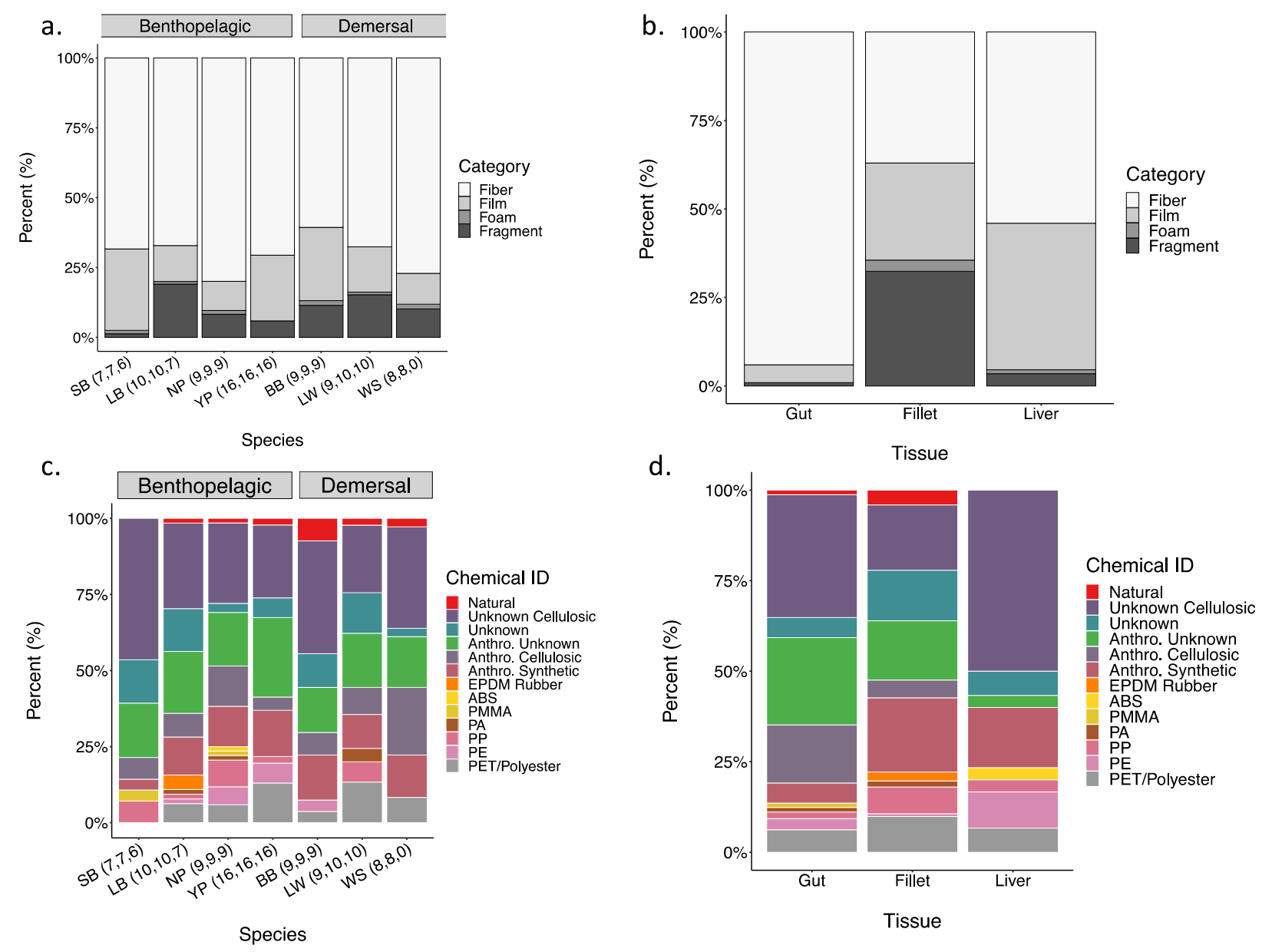

Figure S4. Relative abundance of suspected microplastic morphologies and chemical ID based on Raman spectroscopy. (a) Morphology of particles in each species. Sample sizes are included in brackets for Smallmouth Bass (SB), Largemouth Bass (LB), Northern Pike (NP), Yellow Perch (YP), Brown Bullhead (BB), Lake Whitefish (LW), and White Sucker (WS); (b) Morphology of particles in each tissue; (c) Chemical ID of particles in each species. Sample sizes are included in brackets for all species; (d) Chemical ID of particles in each tissue. (To view colours in this figure, the reader is referred to the Web version of this article). 


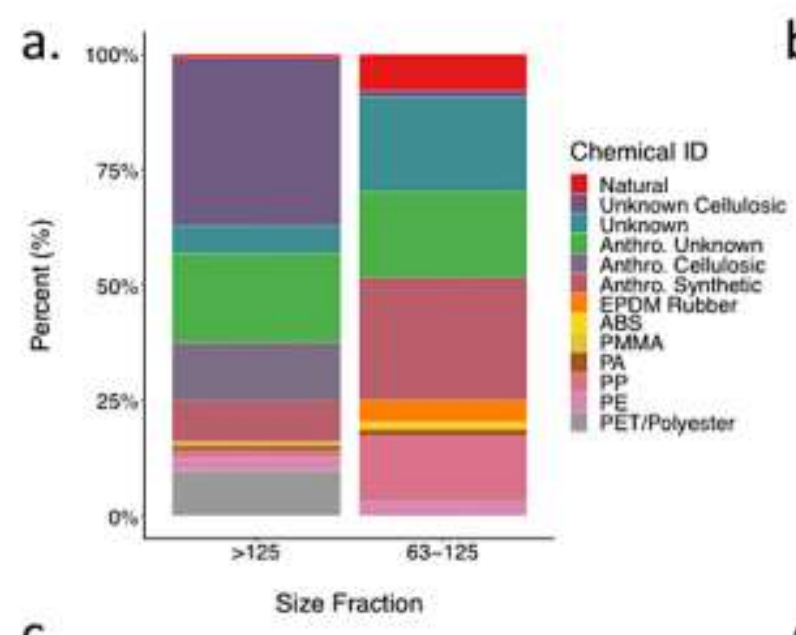

C.

b.
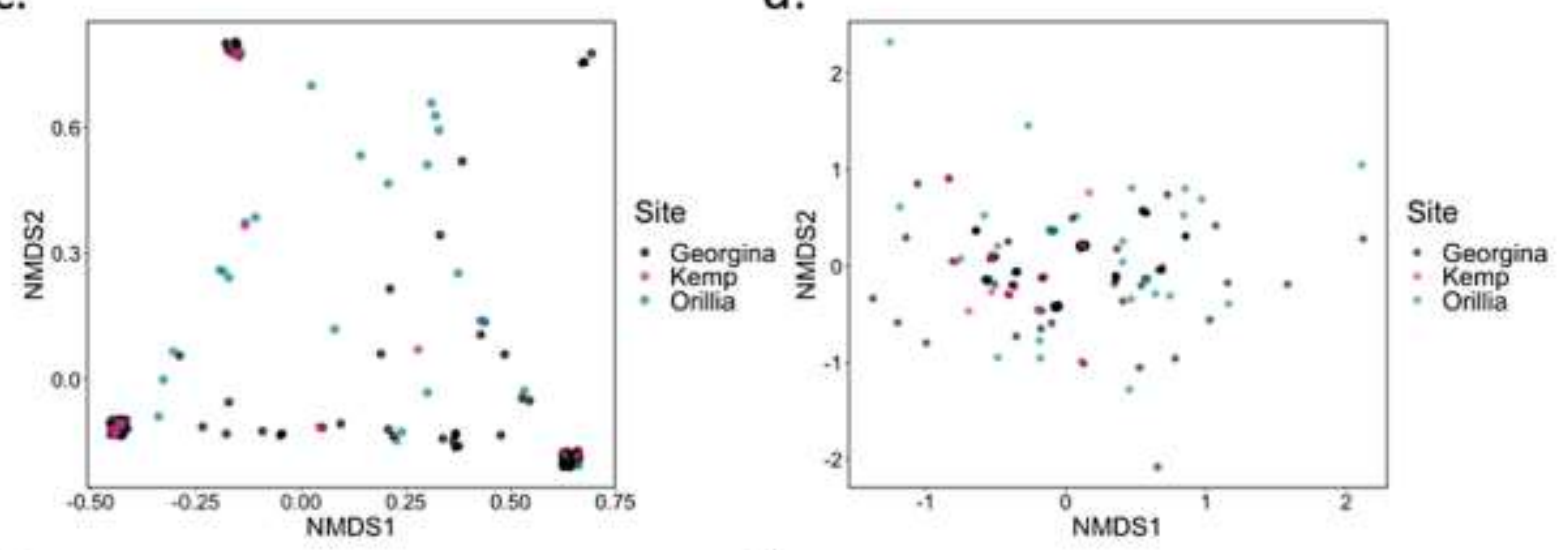

e.

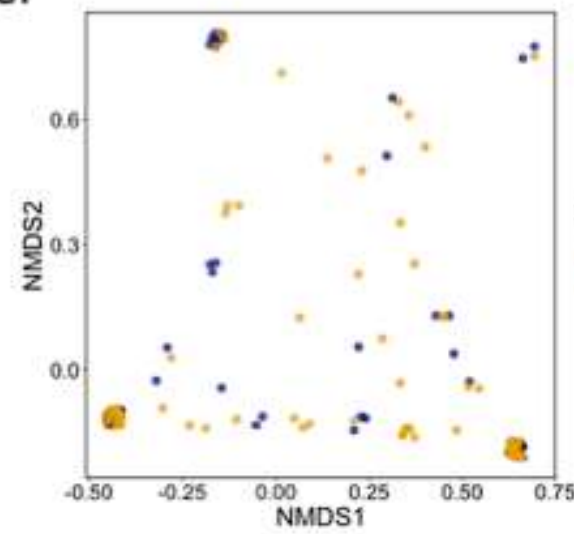

f.

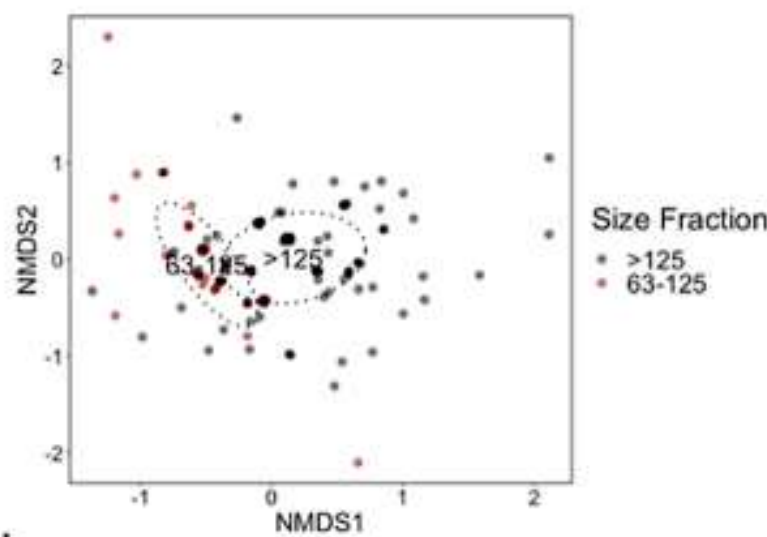

d.

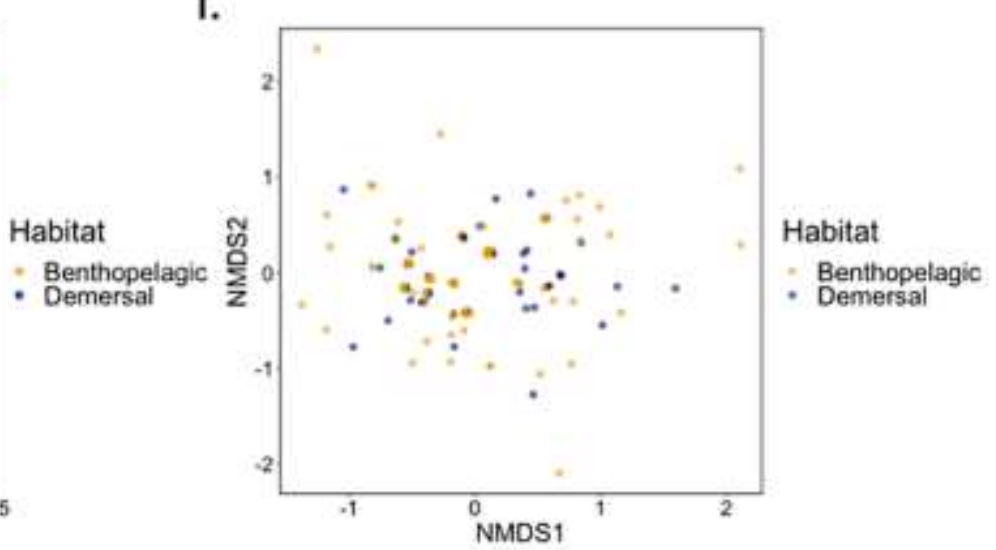

Figure S5. Suspected microplastic morphology and chemical ID assemblages in fish samples. (a) Relative abundance of suspected microplastic chemical IDs based on Raman spectroscopy in fish samples, grouped by size fraction: $>125 \mu \mathrm{m}$ and $63-125 \mu \mathrm{m}$. Gut tissues did not have a $63-125 \mu \mathrm{m}$ size fraction; (b) nMDS analysis of suspected microplastic chemical IDs based on Raman spectroscopy in fish samples, grouped by size fraction. Stress value $=0.15$; (c) nMDS analysis of particle morphology assemblages, grouped by site. Stress value $=0.068$; (d) nMDS analysis of particle chemical ID assemblages, grouped by site. Stress value $=0.15$ (e) nMDS analysis of particle morphology assemblages, grouped by habitat. Stress value $=0.068$; (f) nMDS analysis of particle chemical ID assemblages, grouped by habitat. Stress value $=0.15$. nMDS analysis used Euclidean distance and 999 permutations. 


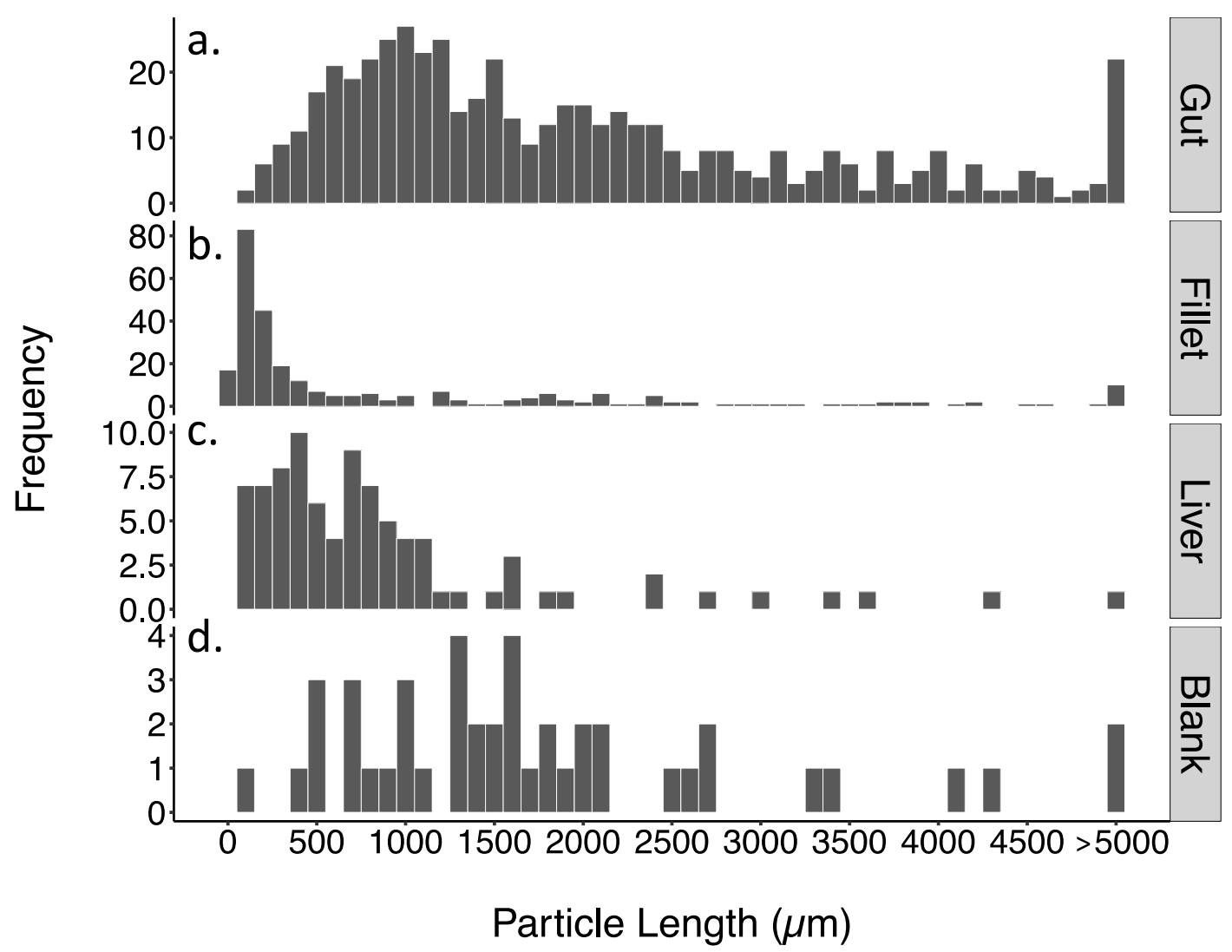

Figure S6. Size histograms of all suspected microplastic lengths $(\mu \mathrm{m})$ in fish tissue samples after blank subtraction and in blanks (note that samples were not blank subtracted by size). (a) Gut; (b) fillet; (c) liver; (d) blanks. 


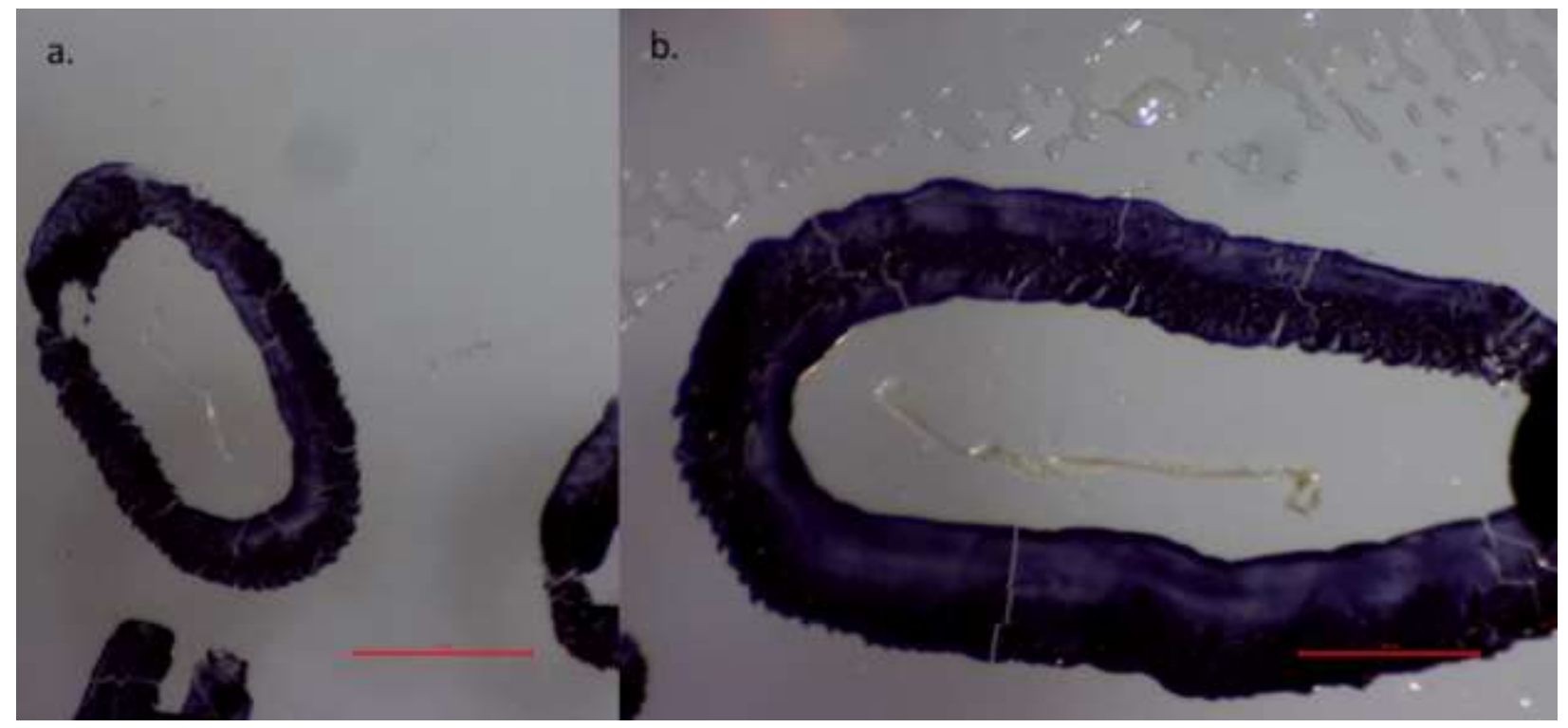

Figure S7. Examples of films $>1000 \mu \mathrm{m}$ found in liver. (a) $1906 \mu \mathrm{m}$; (b) $2982 \mu \mathrm{m}$. 


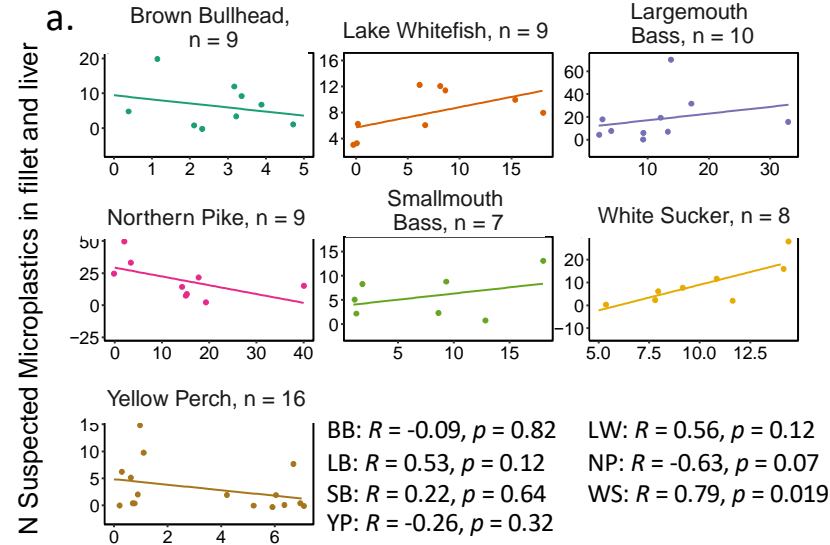

N Suspected Microplastics in gut
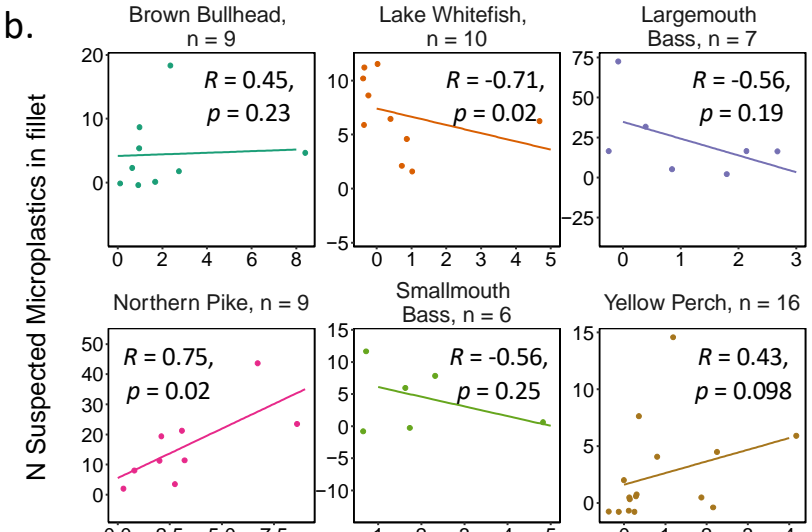

Smallmouth

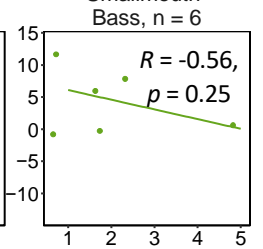

Yellow Perch, $n=16$

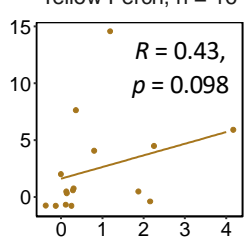

N Suspected Microplastics in liv er

Figure S8. Correlation between the number of suspected microplastic particles in different tissues, using Spearman's rank correlation. (a) Species-specific correlations between the number of suspected microplastics in the gut and in the fillet and liver. One Lake Whitefish (LW) was excluded as it did not have gut data; (b) Species-specific correlations between the number of suspected microplastics in the liver and in the fillet. Note that White Sucker does not have liver data. For all, regression line, rho (R), and pvalue are indicated. 

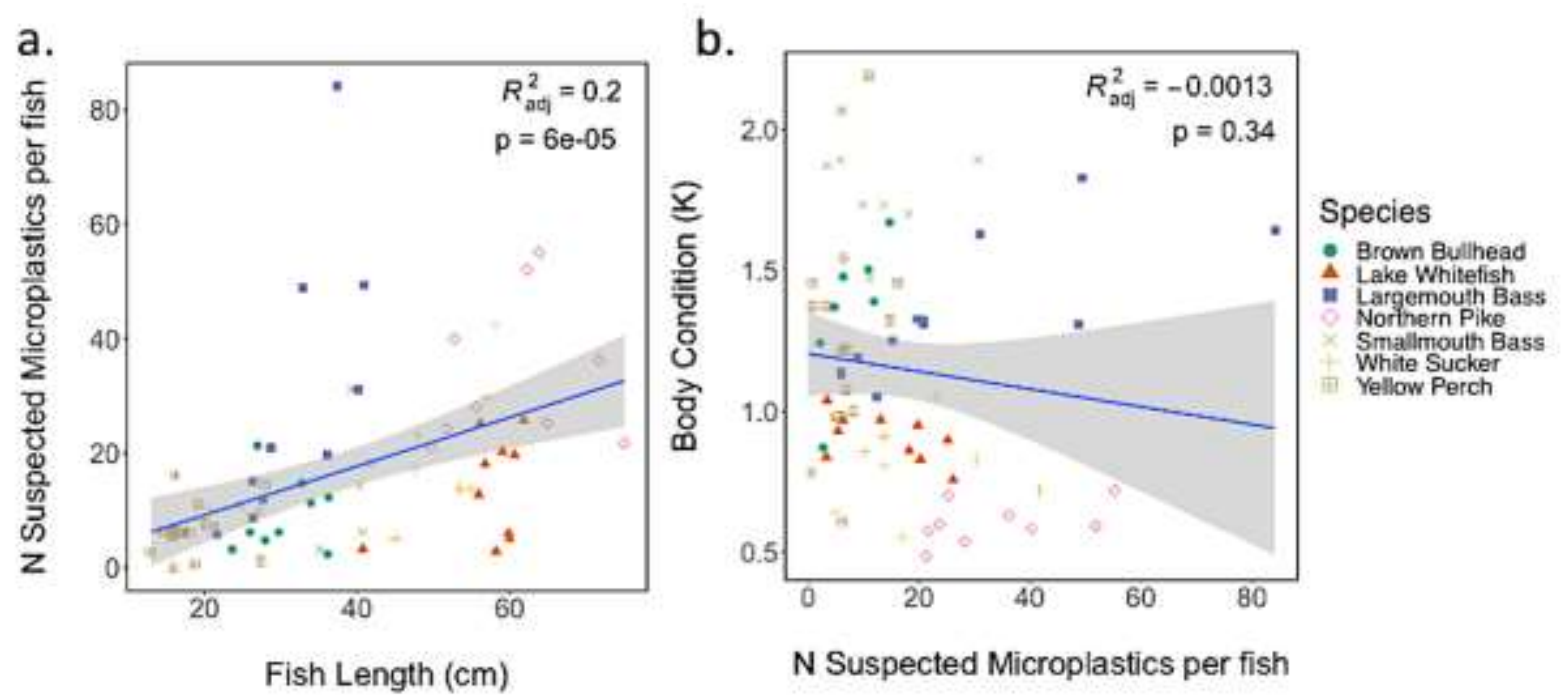

Figure S9. Linear regression analysis between specific life-history traits and the number $(\mathrm{N})$ of suspected microplastics per fish (across all tissues). (a) Fish total length; (b) Body condition. For all, regression line with $95 \%$ confidence interval, adjusted $\mathrm{R}^{2}$, and $\mathrm{p}$-value are indicated. 


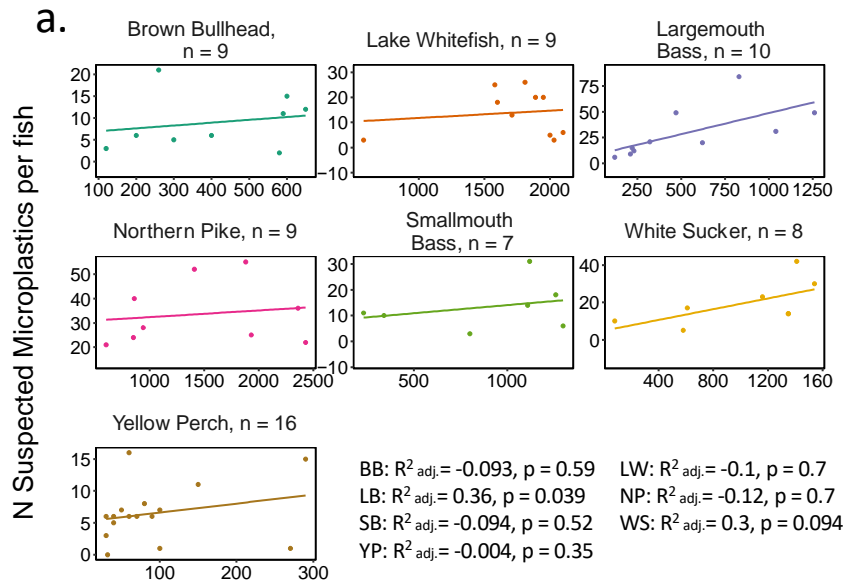

Fish Mass (g) b

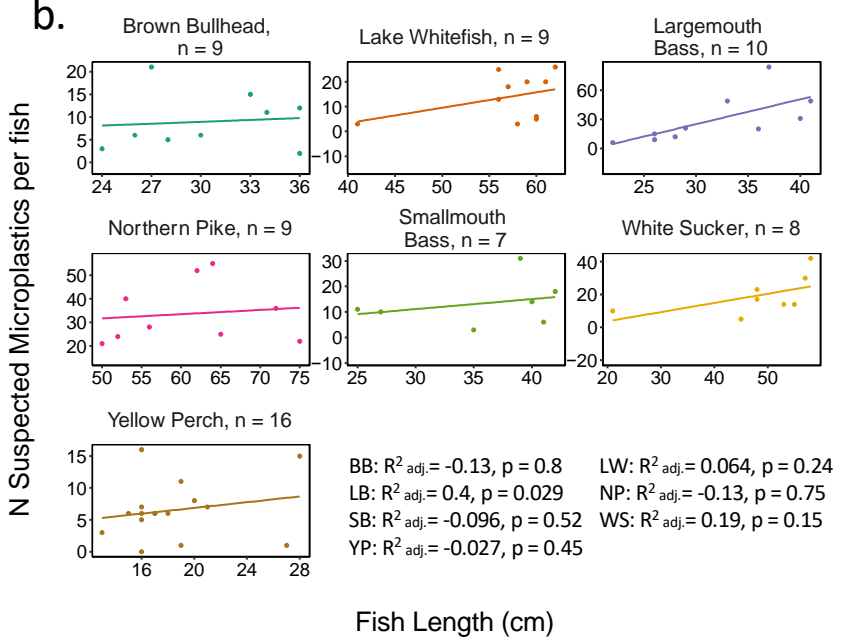

Figure S10. Linear regression analysis between fish size and the number $(\mathrm{N})$ of suspected microplastic particles per fish (across all tissues), for each species. (a) Fish mass; (b) Fish total length. For each species, regression line with $95 \%$ confidence interval, adjusted $\mathrm{R}^{2}$, and $\mathrm{p}$-value are indicated. 
a.

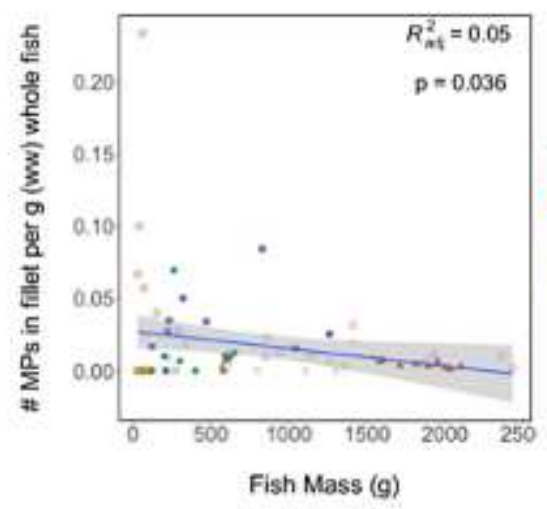

c.

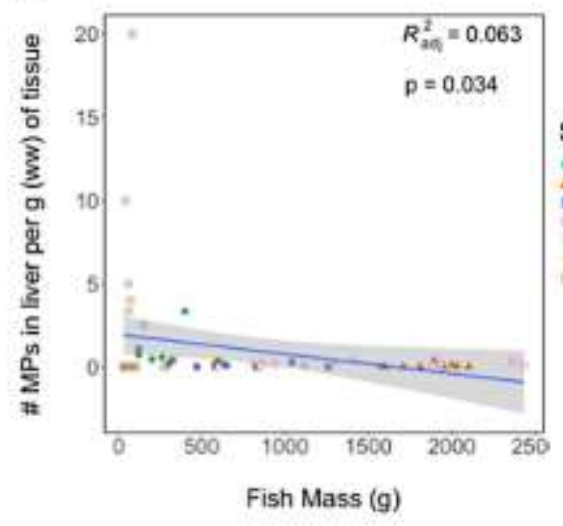

b.

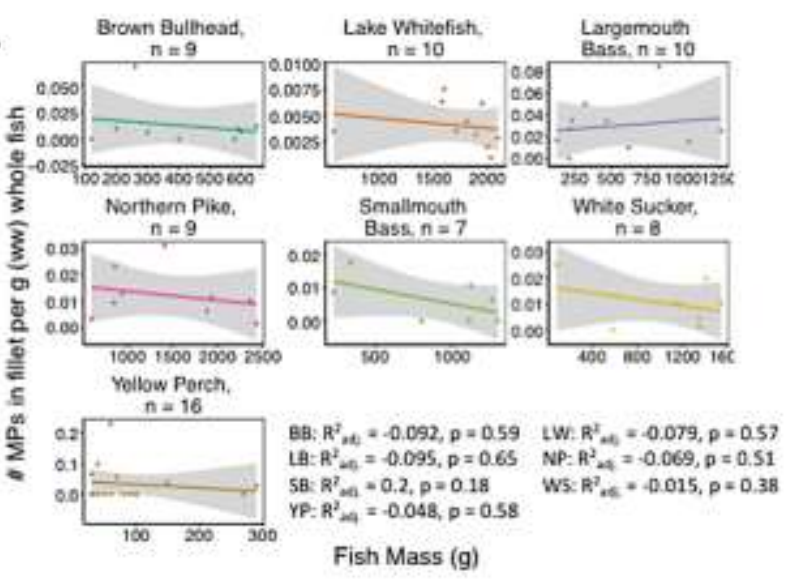

d.

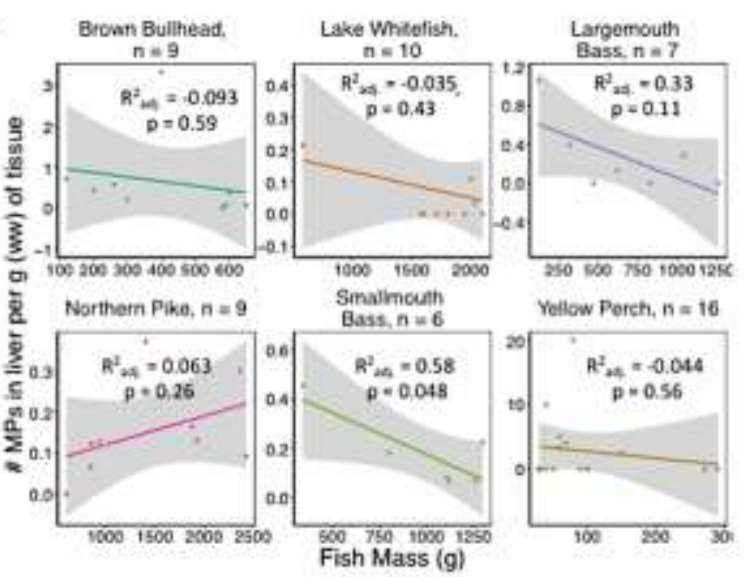

Figure S11. Linear regression analysis between fish mass and the number $(\mathrm{N})$ of suspected microplastics (MPs) in the fillet and liver tissues per gram wet weight (ww), represented in two ways. (a) Number of MPs in fillets only, for all individuals; (b) number of MPs in fillets, by species; (c) number of MPs in liver, for all individuals; (d) number of MPs in liver, by species. For all, regression line with $95 \%$ confidence interval, adjusted $\mathrm{R}^{2}$, and $\mathrm{p}$-value are indicated. 
a.

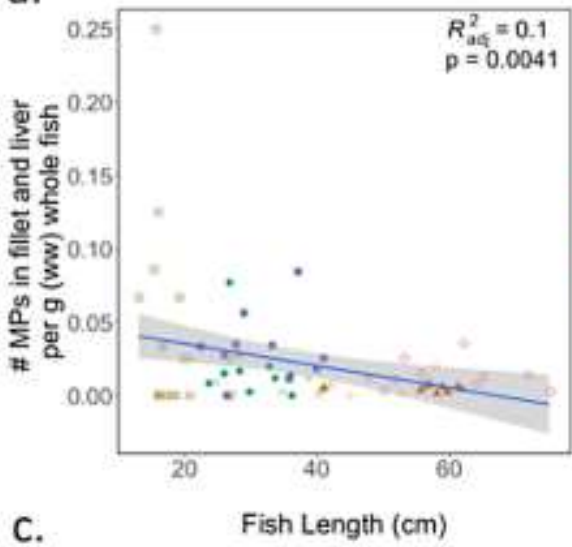

c.
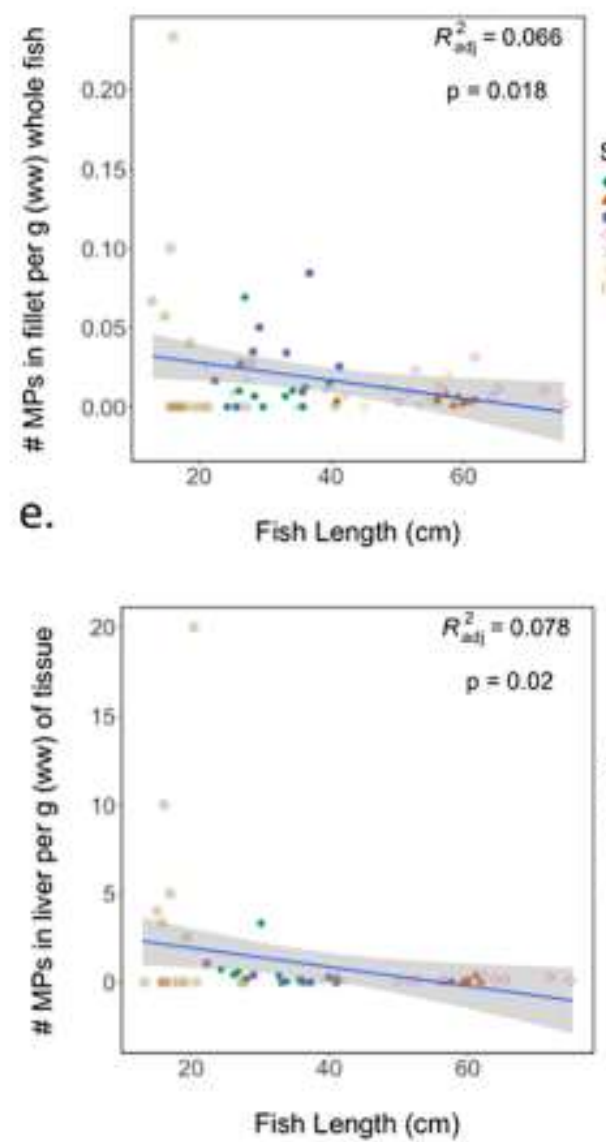

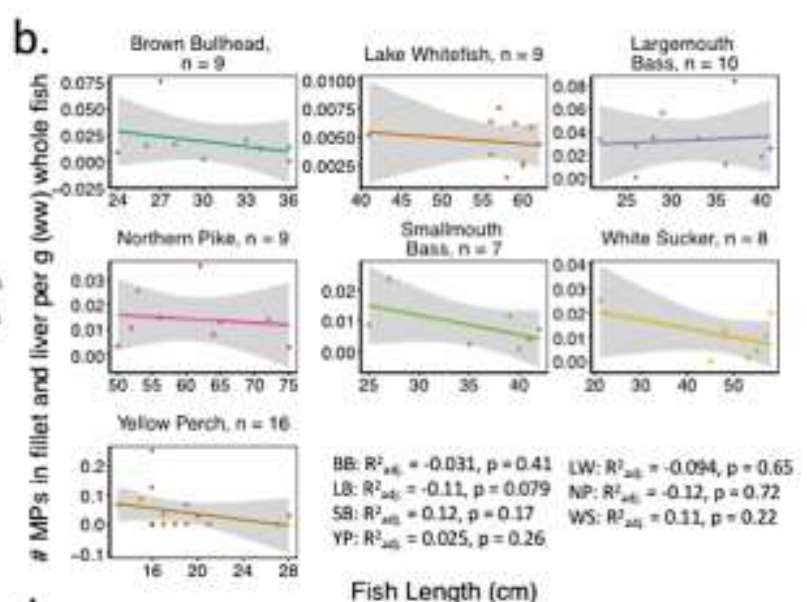

d.

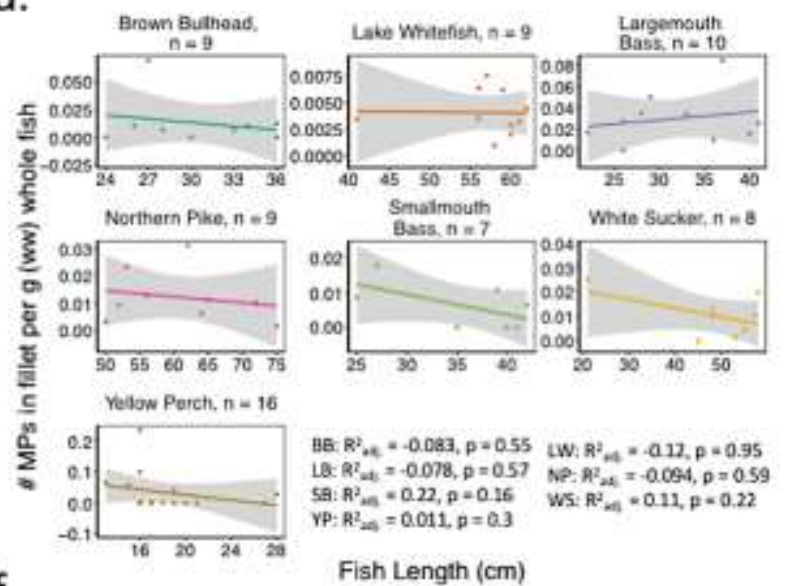

f.

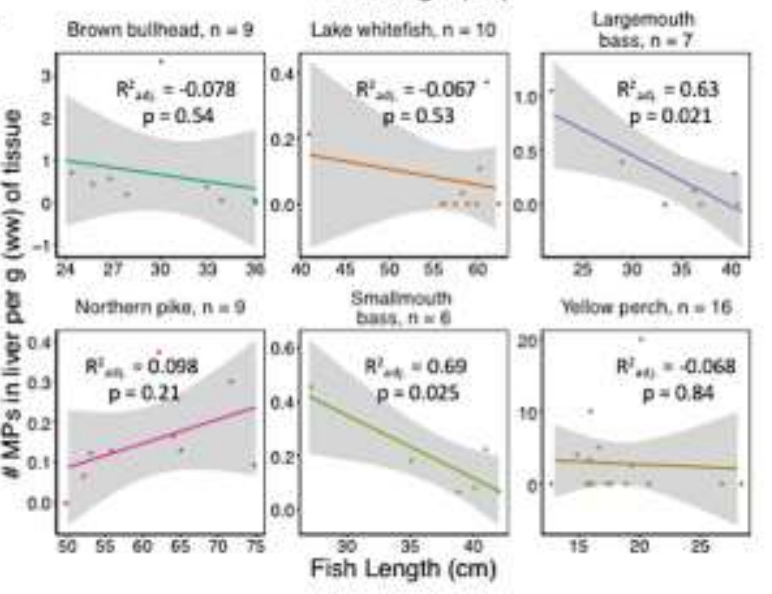

Figure S12. Linear regression analysis between fish total length and the number $(\mathrm{N})$ of suspected microplastics (MPs) in the fillet and liver tissues per gram wet weight (ww), represented in three ways. (a) Number of MPs in fillet and liver tissue per gram (ww) of whole fish, for all individuals; (b) number of MPs in fillet and liver tissue per gram (ww) of whole fish, by species; (c) number of MPs in fillets only per gram (ww) of whole fish, for all individuals; (d) number of MPs in fillets per gram (ww) of whole fish, by species; (e) number of MPs in liver per gram (ww) of tissue, for all individuals; (f) number of MPs in liver per gram (ww) of tissue, by species. For all, regression line with $95 \%$ confidence interval, adjusted $\mathrm{R}^{2}$, and p-value are indicated. 
a.

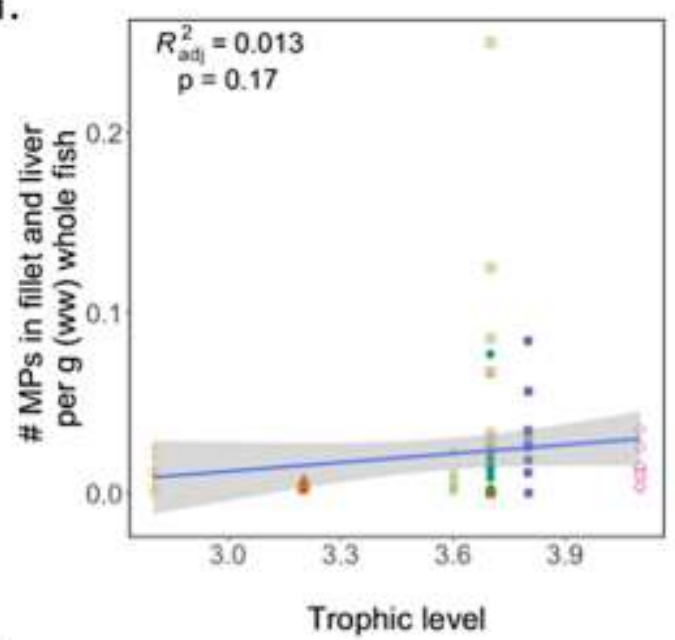

C.

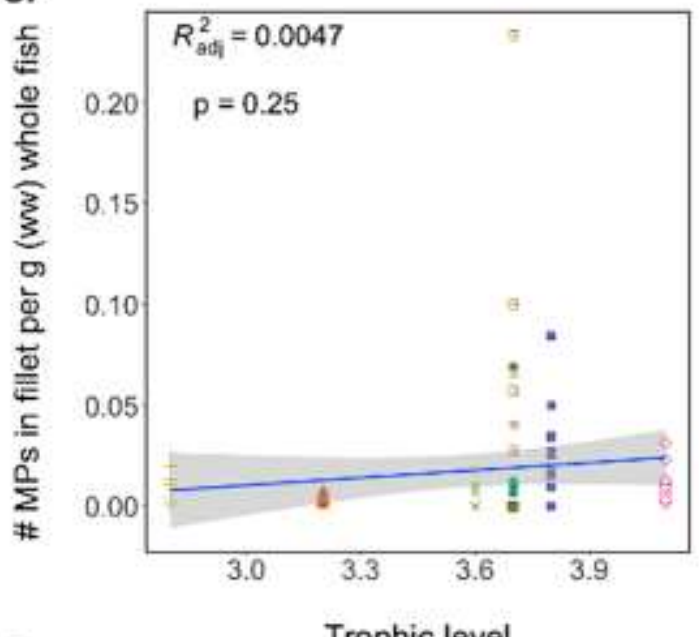

e.

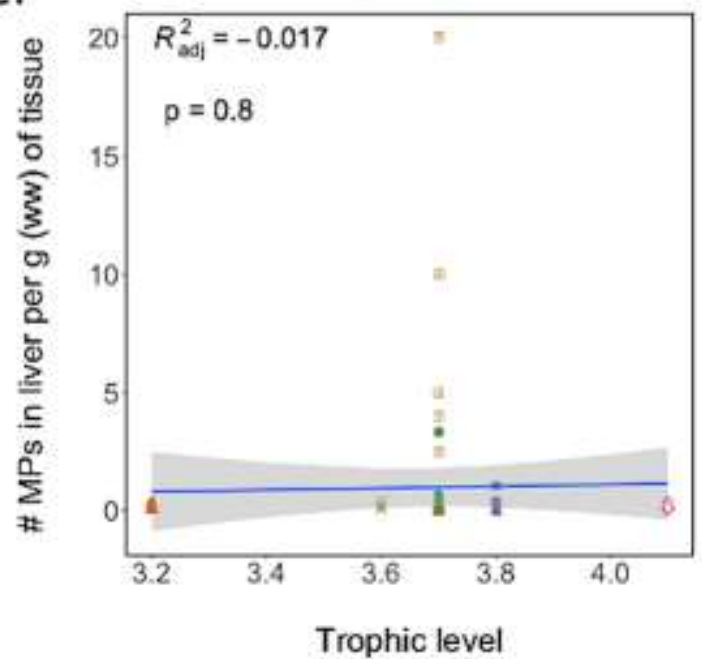

b.

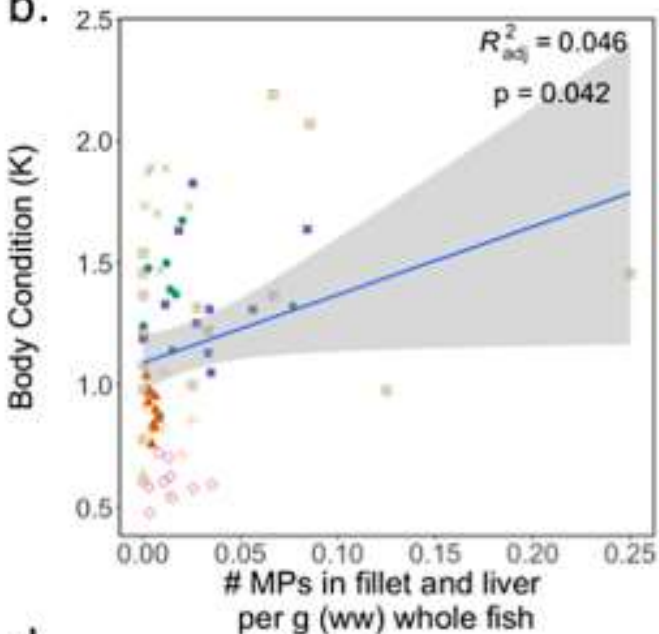

Species

- Brown Bullhead

- Lake Whilefish

Largemouth Bass

Northern Pike
Smalmouth Bass

White Sucker

Yellow Perch d.

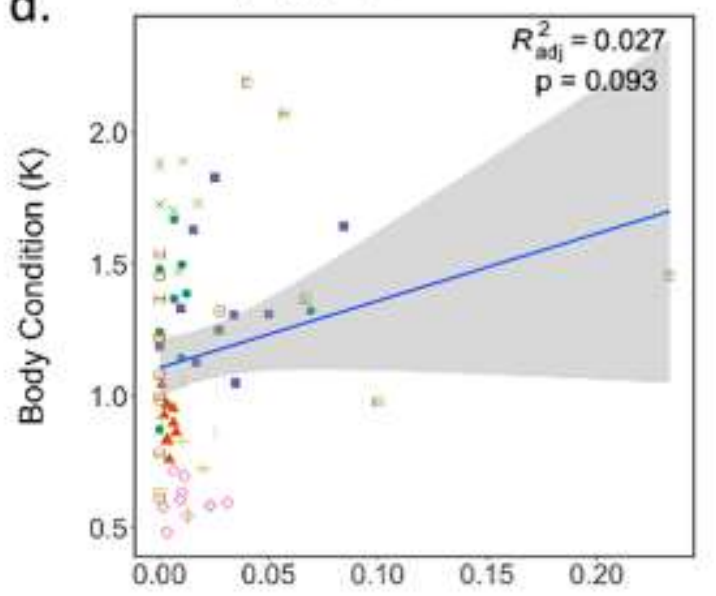

\# MPs in fillet per $g(w w)$ whole fish

f.

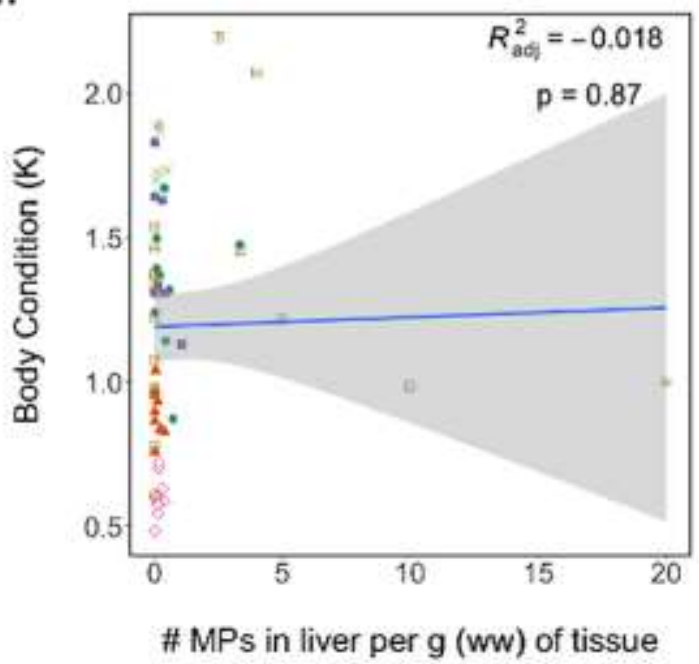

Figure S13. Linear regression analysis between specific life-history traits and the number $(\mathrm{N})$ of suspected microplastic (MP) particles in fillet and liver tissues per gram wet weight (ww), represented in three ways. (a) Trophic level and the number of MPs in fillet and liver tissues per gram (ww) of whole fish; (b) Number of MPs in fillet and liver tissues per gram (ww) of whole fish and body condition; (c) Trophic level and the 
number of MPs in the fillet per gram (ww) of whole fish; (d) Number of MPs in the fillet per gram (ww) of whole fish and body condition; (e) Trophic level and number of MPs in the liver per gram (ww) of liver tissue; (f) Number of MPs in the liver per gram (ww) and body condition. For all, regression line with 95\% confidence interval, adjusted $\mathrm{R}^{2}$, and $\mathrm{p}$-value are indicated. 


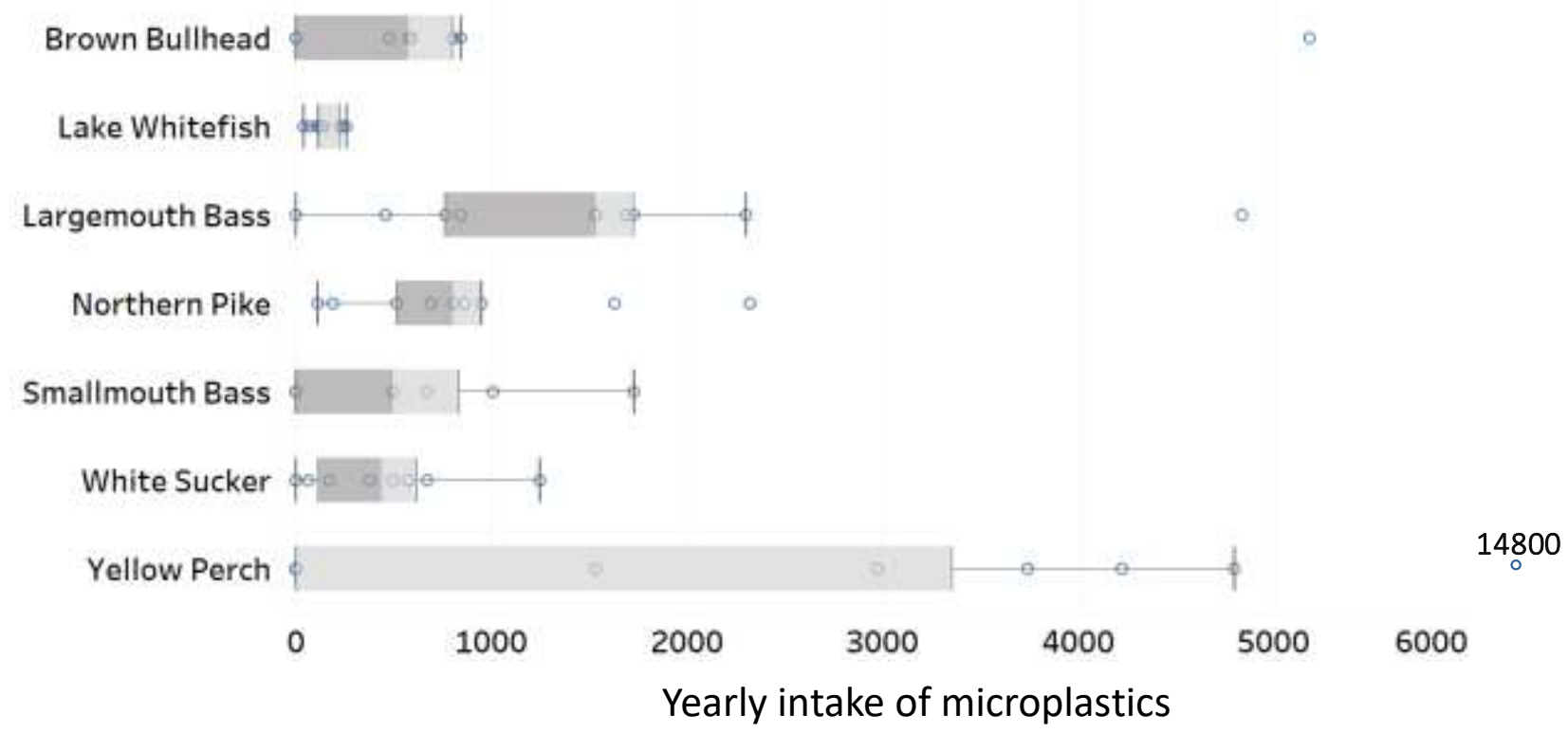

Figure S14. Estimated yearly intake of number of microplastics from consuming studied fish from Lake Simcoe, Ontario, Canada. 
Table S1. Collected species of freshwater fish from Lake Simcoe. Information on habitat, trophic level, sample site, sample size (n), fish mass ( $\mathrm{g}$ ), and fish total length (TL, cm). Trophic level and habitat information was obtained from an online database (Fishbase) ${ }^{3}$.

\begin{tabular}{|c|c|c|c|c|c|c|}
\hline Habitat & Taxa (Common Name) & $\begin{array}{l}\text { Trophic } \\
\text { Level }\end{array}$ & Sample Site & $\mathbf{n}$ & $\begin{array}{l}\text { Range of fish } \\
\text { mass (g) }\end{array}$ & $\begin{array}{l}\text { Range of fish } \\
\text { TL }(\mathrm{cm})\end{array}$ \\
\hline \multirow[t]{8}{*}{ Benthopelagic } & \multirow{2}{*}{$\begin{array}{l}\text { Micropterus dolomieu } \\
\text { (Smallmouth Bass) }\end{array}$} & \multirow[t]{2}{*}{3.6} & Georgina Island & 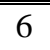 & $230-1300$ & $25-42$ \\
\hline & & & Orillia & 1 & 1110 & 40 \\
\hline & \multirow{2}{*}{$\begin{array}{l}\text { Micropterus salmoides } \\
\text { (Largemouth Bass) }\end{array}$} & \multirow[t]{2}{*}{3.8} & Georgina Island & 5 & $120-320$ & $22-29$ \\
\hline & & & Orillia & 5 & $470-1260$ & $33-41$ \\
\hline & \multirow{2}{*}{$\begin{array}{c}\text { Esox lucius } \\
\text { (Northern Pike) }\end{array}$} & \multirow[t]{2}{*}{4.1} & Georgina Island & 5 & $1410-2430$ & $62-75$ \\
\hline & & & Orillia & 4 & $600-940$ & $50-56$ \\
\hline & \multirow{2}{*}{$\begin{array}{l}\text { Perca flavescens } \\
\text { (Yellow Perch) }\end{array}$} & \multirow[t]{2}{*}{3.7} & Georgina Island & 10 & $30-290$ & $16-28$ \\
\hline & & & Kempenfelt Bay & 6 & $30-70$ & $13-16$ \\
\hline \multirow[t]{6}{*}{ Demersal } & \multirow{2}{*}{$\begin{array}{l}\text { Ameiurus nebulosus } \\
\text { (Brown Bullhead) }\end{array}$} & \multirow[t]{2}{*}{3.7} & Georgina Island & 4 & $120-590$ & $24-34$ \\
\hline & & & Orillia & 5 & $260-650$ & $27-36$ \\
\hline & \multirow{2}{*}{$\begin{array}{l}\text { Coregonus clupeaformis } \\
\text { (Lake Whitefish) }\end{array}$} & \multirow[t]{2}{*}{3.2} & & 5 & & \\
\hline & & & Kempenfelt Bay & 5 & $580-2100$ & $41-60$ \\
\hline & \multirow[t]{2}{*}{$\begin{array}{l}\text { Catostomus commersonit } \\
\text { (White Sucker) }\end{array}$} & \multirow[t]{2}{*}{2.8} & & 3 & & \\
\hline & & & Orillia & 5 & $1160-1540$ & $53-58$ \\
\hline
\end{tabular}


Table S2. Spike recovery tests for digestion protocol.

\begin{tabular}{|c|c|c|c|c|}
\hline Treatment & $\begin{array}{l}\text { Microplastic } \\
\text { morphology and } \\
\text { color }\end{array}$ & Spike & Recovery & Total \% recovery \\
\hline \multirow[t]{5}{*}{ Rainbow trout } & Red fiber & 10 & 7 & \multirow[t]{5}{*}{88} \\
\hline & White fragment & 10 & 10 & \\
\hline & Purple sphere & 10 & 9 & \\
\hline & White sphere & 10 & 8 & \\
\hline & Red fragment & 10 & 10 & \\
\hline \multirow[t]{5}{*}{ White sucker } & Red fiber & 10 & 8 & \multirow[t]{5}{*}{90} \\
\hline & White fragment & 10 & 10 & \\
\hline & Purple sphere & 10 & 9 & \\
\hline & White sphere & 10 & 8 & \\
\hline & Red fragment & 10 & 10 & \\
\hline \multirow[t]{5}{*}{ Salmon oil (4 g) } & Red fiber & 10 & 8 & \multirow[t]{5}{*}{86} \\
\hline & White fragment & 10 & 9 & \\
\hline & Purple sphere & 10 & 10 & \\
\hline & White sphere & 10 & 7 & \\
\hline & Red fragment & 10 & 9 & \\
\hline
\end{tabular}


Table S3. Summary of suspected microplastics in blank samples from the $>125 \mu \mathrm{m}$ size fraction. The average of each colour-category combination was subtracted from fish tissue samples. There were no particles found in blank samples for the $63 \mu \mathrm{m}$ size fraction.

\begin{tabular}{|l|l|l|l|l|l|l|l|l|}
\hline Blank \# & $\begin{array}{l}\text { Blue } \\
\text { fiber }\end{array}$ & $\begin{array}{l}\text { Red } \\
\text { fiber }\end{array}$ & $\begin{array}{l}\text { Black } \\
\text { fiber }\end{array}$ & $\begin{array}{l}\text { Clear } \\
\text { fiber }\end{array}$ & $\begin{array}{l}\text { Green } \\
\text { fiber }\end{array}$ & $\begin{array}{l}\text { Purple } \\
\text { fiber }\end{array}$ & $\begin{array}{l}\text { Black } \\
\text { fragment }\end{array}$ & Total \\
\hline $\mathbf{1}$ & 2 & 1 & 0 & 0 & 0 & 0 & 0 & 3 \\
\hline $\mathbf{2}$ & 0 & 0 & 0 & 0 & 0 & 0 & 0 & 0 \\
\hline $\mathbf{3}$ & 1 & 0 & 0 & 0 & 0 & 0 & 0 & 1 \\
\hline $\mathbf{4}$ & 2 & 0 & 0 & 0 & 0 & 0 & 0 & 2 \\
\hline $\mathbf{5}$ & 2 & 0 & 0 & 0 & 0 & 0 & 0 & 2 \\
\hline $\mathbf{6}$ & 1 & 0 & 0 & 5 & 0 & 0 & 0 & 6 \\
\hline $\mathbf{7}$ & 3 & 0 & 0 & 6 & 0 & 0 & 0 & 9 \\
\hline $\mathbf{8}$ & 0 & 0 & 0 & 1 & 0 & 0 & 1 & 2 \\
\hline $\mathbf{9}$ & 1 & 0 & 5 & 1 & 0 & 0 & 0 & 7 \\
\hline $\mathbf{1 0}$ & 1 & 3 & 3 & 4 & 1 & 1 & 0 & 13 \\
\hline Total & 13 & 4 & 8 & 17 & 1 & 1 & 1 & 45 \\
\hline
\end{tabular}


Table S4. Summary of suspected microplastic categories in all studied tissues (GI tract, fillet, and liver) in fish from Lake Simcoe. Values include suspected microplastics in both the $>125$ and $63 \mu \mathrm{m}$ size fractions and suspected microplastics in only one fillet.

\begin{tabular}{|l|l|l|l|l|l|l|}
\hline Sample & Site & Fiber & Fragment & Film & Foam & Total \\
\hline SB1 & Georgina Island & 21 & 0 & 4 & 0 & 25 \\
\hline SB2 & Georgina Island & 1 & 0 & 2 & 0 & 3 \\
\hline SB3 & Georgina Island & 8 & 0 & 2 & 0 & 10 \\
\hline SB4 & Georgina Island & 0 & 0 & 6 & 0 & 6 \\
\hline SB5 & Georgina Island & 1 & 0 & 6 & 0 & 7 \\
\hline SB6 & Georgina Island & 10 & 1 & 2 & 1 & 14 \\
\hline SB7 & Orillia & 13 & 0 & 1 & 0 & 14 \\
\hline LB1 & Georgina Island & 7 & 0 & 5 & 0 & 12 \\
\hline LB2 & Georgina Island & 9 & 1 & 3 & 0 & 13 \\
\hline LB3 & Georgina Island & 9 & 0 & 0 & 0 & 9 \\
\hline LB4 & Georgina Island & 3 & 0 & 2 & 0 & 5 \\
\hline LB5 & Georgina Island & 0 & 0 & 8 & 0 & 8 \\
\hline LB6 & Orillia & 19 & 1 & 2 & 1 & 23 \\
\hline LB7 & Orillia & 19 & 25 & 5 & 0 & 49 \\
\hline LB8 & Orillia & 21 & 12 & 0 & 0 & 33 \\
\hline LB9 & Orillia & 38 & 1 & 1 & 1 & 41 \\
\hline LB10 & Orillia & 16 & 0 & 1 & 0 & 17 \\
\hline YP1 & Georgina Island & 7 & 0 & 0 & 0 & 7 \\
\hline YP2 & Georgina Island & 7 & 0 & 0 & 0 & 7 \\
\hline YP3 & Georgina Island & 6 & 0 & 0 & 0 & 6 \\
\hline YP4 & Georgina Island & 4 & 0 & 2 & 0 & 6 \\
\hline YP5 & Georgina Island & 1 & 0 & 0 & 0 & 1 \\
\hline YP6 & Georgina Island & 3 & 0 & 5 & 0 & 8 \\
\hline YP7 & Georgina Island & 7 & 0 & 1 & 0 & 8 \\
\hline YP8 & Georgina Island & 1 & 0 & 0 & 0 & 1 \\
\hline YP9 & Georgina Island & 8 & 1 & 2 & 0 & 11 \\
\hline YP10 & Georgina Island & 4 & 0 & 2 & 0 & 6 \\
\hline YP11 & Kempenfelt Bay & 3 & 1 & 5 & 0 & 9 \\
\hline YP12 & Kempenfelt Bay & 1 & 1 & 0 & 0 & 2 \\
\hline YP13 & Kempenfelt Bay & 1 & 1 & 2 & 0 & 4 \\
\hline YP14 & Kempenfelt Bay & 3 & 1 & 0 & 0 & 4 \\
\hline YP15 & Kempenfelt Bay & 4 & 0 & 1 & 0 & 5 \\
\hline YP16 & Kempenfelt Bay & 0 & 0 & 0 & 0 & 0 \\
\hline NP1 & Georgina Island & 8 & 1 & 5 & 0 & 14 \\
\hline NP2 & Georgina Island & 46 & 0 & 2 & 1 & 49 \\
\hline NP3 & Georgina Island & 18 & 6 & 6 & 0 & 30 \\
\hline NP4 & Georgina Island & 17 & 3 & 4 & 0 & 24 \\
\hline NP5 & Georgina Island & 17 & 0 & 3 & 0 & 20 \\
\hline NP6 & Orillia & 22 & 5 & 1 & 2 & 30 \\
\hline & & & & \\
\hline
\end{tabular}




\begin{tabular}{|l|l|l|l|l|l|l|}
\hline NP7 & Orillia & 19 & 1 & 0 & 0 & 20 \\
\hline NP8 & Orillia & 17 & 1 & 2 & 0 & 20 \\
\hline NP9 & Orillia & 19 & 2 & 1 & 0 & 22 \\
\hline BB1 & Georgina Island & 4 & 3 & 0 & 1 & 8 \\
\hline BB2 & Georgina Island & 2 & 0 & 2 & 0 & 4 \\
\hline BB3 & Georgina Island & 1 & 0 & 4 & 0 & 5 \\
\hline BB4 & Georgina Island & 2 & 0 & 1 & 0 & 3 \\
\hline BB5 & Orillia & 10 & 0 & 3 & 0 & 13 \\
\hline BB6 & Orillia & 6 & 0 & 0 & 0 & 6 \\
\hline BB7 & Orillia & 5 & 2 & 5 & 0 & 12 \\
\hline BB8 & Orillia & 2 & 0 & 0 & 0 & 2 \\
\hline BB9 & Orillia & 5 & 2 & 1 & 0 & 8 \\
\hline WS1 & Georgina Island & 5 & 0 & 0 & 0 & 5 \\
\hline WS2 & Georgina Island & 9 & 4 & 0 & 0 & 13 \\
\hline WS3 & Georgina Island & 8 & 1 & 0 & 0 & 9 \\
\hline WS4 & Orillia & 14 & 2 & 1 & 0 & 17 \\
\hline WS5 & Orillia & 16 & 0 & 11 & 1 & 28 \\
\hline WS6 & Orillia & 9 & 2 & 0 & 0 & 11 \\
\hline WS7 & Orillia & 13 & 0 & 0 & 0 & 13 \\
\hline WS8 & Orillia & 17 & 3 & 1 & 1 & 22 \\
\hline LW1 & Georgina Island & 13 & 1 & 3 & 0 & 17 \\
\hline LW2 & Georgina Island & 13 & 4 & 2 & 1 & 20 \\
\hline LW3 & Georgina Island & 10 & 1 & 1 & 0 & 12 \\
\hline LW4 & Georgina Island & 8 & 2 & 4 & 0 & 14 \\
\hline LW5 & Georgina Island & 16 & 5 & 1 & 0 & 22 \\
\hline LW6 & Kempenfelt Bay & 9 & 1 & 0 & 0 & 10 \\
\hline LW7 & Kempenfelt Bay & 1 & 1 & 1 & 0 & 3 \\
\hline LW8 & Kempenfelt Bay & 1 & 0 & 1 & 0 & 2 \\
\hline LW9 & Kempenfelt Bay & 0 & 0 & 3 & 0 & 3 \\
\hline LW10 & Kempenfelt Bay & 0 & 1 & 1 & 0 & 2 \\
\hline & Total & 637 & 100 & 140 & 10 & 887 \\
\hline & & & & & \\
\hline
\end{tabular}


Table S5. Summary of suspected microplastic categories in gastrointestinal (GI) tracts of fish from Lake Simcoe, after blank subtraction. There was no $63 \mu \mathrm{m}$ size fraction for GI tracts and one Lake Whitefish GI tract was not dissected (LW7).

\begin{tabular}{|l|l|l|l|l|l|l|}
\hline Sample & Site & Fiber & Fragment & Film & Foam & Total \\
\hline SB1 & Georgina Island & 18 & 0 & 0 & 0 & 18 \\
\hline SB2 & Georgina Island & 1 & 0 & 0 & 0 & 1 \\
\hline SB3 & Georgina Island & 8 & 0 & 1 & 0 & 9 \\
\hline SB4 & Georgina Island & 0 & 0 & 1 & 0 & 1 \\
\hline SB5 & Georgina Island & 1 & 0 & 1 & 0 & 2 \\
\hline SB6 & Georgina Island & 9 & 0 & 0 & 0 & 9 \\
\hline SB7 & Orillia & 13 & 0 & 0 & 0 & 13 \\
\hline LB1 & Georgina Island & 7 & 0 & 2 & 0 & 9 \\
\hline LB2 & Georgina Island & 3 & 0 & 0 & 0 & 3 \\
\hline LB3 & Georgina Island & 9 & 0 & 0 & 0 & 9 \\
\hline LB4 & Georgina Island & 2 & 0 & 0 & 0 & 2 \\
\hline LB5 & Georgina Island & 0 & 0 & 4 & 0 & 4 \\
\hline LB6 & Orillia & 12 & 0 & 0 & 0 & 12 \\
\hline LB7 & Orillia & 14 & 0 & 0 & 0 & 14 \\
\hline LB8 & Orillia & 17 & 0 & 0 & 0 & 17 \\
\hline LB9 & Orillia & 33 & 0 & 0 & 0 & 33 \\
\hline LB10 & Orillia & 13 & 0 & 0 & 0 & 13 \\
\hline YP1 & Georgina Island & 7 & 0 & 0 & 0 & 7 \\
\hline YP2 & Georgina Island & 7 & 0 & 0 & 0 & 7 \\
\hline YP3 & Georgina Island & 6 & 0 & 0 & 0 & 6 \\
\hline YP4 & Georgina Island & 4 & 0 & 0 & 0 & 4 \\
\hline YP5 & Georgina Island & 1 & 0 & 0 & 0 & 1 \\
\hline YP6 & Georgina Island & 0 & 0 & 1 & 0 & 1 \\
\hline YP7 & Georgina Island & 6 & 0 & 0 & 0 & 6 \\
\hline YP8 & Georgina Island & 1 & 0 & 0 & 0 & 1 \\
\hline YP9 & Georgina Island & 7 & 0 & 0 & 0 & 7 \\
\hline YP10 & Georgina Island & 4 & 0 & 2 & 0 & 6 \\
\hline YP11 & Kempenfelt Bay & 1 & 0 & 0 & 0 & 1 \\
\hline YP12 & Kempenfelt Bay & 1 & 0 & 0 & 0 & 1 \\
\hline YP13 & Kempenfelt Bay & 0 & 0 & 0 & 0 & 0 \\
\hline YP14 & Kempenfelt Bay & 1 & 0 & 0 & 0 & 1 \\
\hline YP15 & Kempenfelt Bay & 4 & 0 & 1 & 0 & 5 \\
\hline YP16 & Kempenfelt Bay & 0 & 0 & 0 & 0 & 0 \\
\hline NP1 & Georgina Island & 0 & 0 & 0 & 0 & 0 \\
\hline NP2 & Georgina Island & 38 & 0 & 2 & 0 & 40 \\
\hline NP3 & Georgina Island & 0 & 0 & 2 & 0 & 2 \\
\hline NP4 & Georgina Island & 3 & 0 & 0 & 0 & 3 \\
\hline NP5 & Georgina Island & 14 & 0 & 1 & 0 & 15 \\
\hline NP6 & Orillia & 18 & 0 & 0 & 0 & 18 \\
\hline & & & & \\
\hline
\end{tabular}




\begin{tabular}{|l|l|l|l|l|l|l|}
\hline NP7 & Orillia & 18 & 1 & 0 & 0 & 19 \\
\hline NP8 & Orillia & 15 & 0 & 0 & 0 & 15 \\
\hline NP9 & Orillia & 14 & 0 & 0 & 0 & 14 \\
\hline BB1 & Georgina Island & 4 & 0 & 0 & 0 & 4 \\
\hline BB2 & Georgina Island & 0 & 0 & 0 & 0 & 0 \\
\hline BB3 & Georgina Island & 0 & 0 & 3 & 0 & 3 \\
\hline BB4 & Georgina Island & 2 & 0 & 0 & 0 & 2 \\
\hline BB5 & Orillia & 2 & 0 & 1 & 0 & 3 \\
\hline BB6 & Orillia & 5 & 0 & 0 & 0 & 5 \\
\hline BB7 & Orillia & 1 & 0 & 0 & 0 & 1 \\
\hline BB8 & Orillia & 2 & 0 & 0 & 0 & 2 \\
\hline BB9 & Orillia & 2 & 1 & 0 & 0 & 3 \\
\hline WS1 & Georgina Island & 5 & 0 & 0 & 0 & 5 \\
\hline WS2 & Georgina Island & 9 & 0 & 0 & 0 & 9 \\
\hline WS3 & Georgina Island & 8 & 0 & 0 & 0 & 8 \\
\hline WS4 & Orillia & 10 & 1 & 0 & 0 & 11 \\
\hline WS5 & Orillia & 14 & 0 & 0 & 0 & 14 \\
\hline WS6 & Orillia & 7 & 1 & 0 & 0 & 8 \\
\hline WS7 & Orillia & 12 & 0 & 0 & 0 & 12 \\
\hline WS8 & Orillia & 14 & 0 & 0 & 0 & 14 \\
\hline LW1 & Georgina Island & 9 & 0 & 0 & 0 & 9 \\
\hline LW2 & Georgina Island & 13 & 0 & 2 & 0 & 15 \\
\hline LW3 & Georgina Island & 6 & 0 & 0 & 0 & 6 \\
\hline LW4 & Georgina Island & 7 & 0 & 1 & 0 & 8 \\
\hline LW5 & Georgina Island & 16 & 1 & 1 & 0 & 18 \\
\hline LW6 & Kempenfelt Bay & 7 & 0 & 0 & 0 & 7 \\
\hline LW7 & Kempenfelt Bay & NA & NA & NA & NA & NA \\
\hline LW8 & Kempenfelt Bay & 0 & 0 & 0 & 0 & 0 \\
\hline LW9 & Kempenfelt Bay & 0 & 0 & 0 & 0 & 0 \\
\hline LW10 & Kempenfelt Bay & 0 & 0 & 0 & 0 & 0 \\
\hline & Total & 485 & 5 & 26 & 0 & 516 \\
\hline & & & & & \\
\hline
\end{tabular}


Table S6 Summary of suspected microplastic categories in one fillet per fish from Lake Simcoe, after blank subtraction. Suspected microplastics in both the $>125 \mu \mathrm{m}$ and $63 \mu \mathrm{m}$ size fractions are included.

\begin{tabular}{|l|l|l|l|l|l|l|}
\hline Sample & Site & Fiber & Fragment & Film & Foam & Total \\
\hline SB1 & Georgina Island & 2 & 0 & 4 & 0 & 6 \\
\hline SB2 & Georgina Island & 0 & 0 & 0 & 0 & 0 \\
\hline SB3 & Georgina Island & 0 & 0 & 1 & 0 & 1 \\
\hline SB4 & Georgina Island & 0 & 0 & 0 & 0 & 0 \\
\hline SB5 & Georgina Island & 0 & 0 & 3 & 0 & 3 \\
\hline SB6 & Georgina Island & 1 & 1 & 1 & 1 & 4 \\
\hline SB7 & Orillia & 0 & 0 & 0 & 0 & 0 \\
\hline LB1 & Georgina Island & 0 & 0 & 3 & 0 & 3 \\
\hline LB2 & Georgina Island & 4 & 1 & 3 & 0 & 8 \\
\hline LB3 & Georgina Island & 0 & 0 & 0 & 0 & 0 \\
\hline LB4 & Georgina Island & 0 & 0 & 1 & 0 & 1 \\
\hline LB5 & Georgina Island & 0 & 0 & 4 & 0 & 4 \\
\hline LB6 & Orillia & 4 & 1 & 2 & 1 & 8 \\
\hline LB7 & Orillia & 5 & 25 & 5 & 0 & 35 \\
\hline LB8 & Orillia & 4 & 12 & 0 & 0 & 16 \\
\hline LB9 & Orillia & 5 & 1 & 1 & 1 & 8 \\
\hline LB10 & Orillia & 3 & 0 & 0 & 0 & 3 \\
\hline YP1 & Georgina Island & 0 & 0 & 0 & 0 & 0 \\
\hline YP2 & Georgina Island & 0 & 0 & 0 & 0 & 0 \\
\hline YP3 & Georgina Island & 0 & 0 & 0 & 0 & 0 \\
\hline YP4 & Georgina Island & 0 & 0 & 0 & 0 & 0 \\
\hline YP5 & Georgina Island & 0 & 0 & 0 & 0 & 0 \\
\hline YP6 & Georgina Island & 1 & 0 & 2 & 0 & 3 \\
\hline YP7 & Georgina Island & 0 & 0 & 0 & 0 & 0 \\
\hline YP8 & Georgina Island & 0 & 0 & 0 & 0 & 0 \\
\hline YP9 & Georgina Island & 1 & 1 & 2 & 0 & 4 \\
\hline YP10 & Georgina Island & 0 & 0 & 0 & 0 & 0 \\
\hline YP11 & Kempenfelt Bay & 1 & 1 & 5 & 0 & 7 \\
\hline YP12 & Kempenfelt Bay & 0 & 1 & 0 & 0 & 1 \\
\hline YP13 & Kempenfelt Bay & 1 & 1 & 0 & 0 & 2 \\
\hline YP14 & Kempenfelt Bay & 1 & 1 & 0 & 0 & 2 \\
\hline YP15 & Kempenfelt Bay & 0 & 0 & 0 & 0 & 0 \\
\hline YP16 & Kempenfelt Bay & 0 & 0 & 0 & 0 & 0 \\
\hline NP1 & Georgina Island & 7 & 1 & 3 & 0 & 11 \\
\hline NP2 & Georgina Island & 5 & 0 & 0 & 1 & 6 \\
\hline NP3 & Georgina Island & 14 & 6 & 2 & 0 & 22 \\
\hline NP4 & Georgina Island & 8 & 3 & 1 & 0 & 12 \\
\hline NP5 & Georgina Island & 2 & 0 & 0 & 0 & 2 \\
\hline NP6 & Orillia & 3 & 4 & 1 & 2 & 10 \\
\hline & & & & & \\
\hline
\end{tabular}




\begin{tabular}{|l|l|l|l|l|l|l|}
\hline NP7 & Orillia & 1 & 0 & 0 & 0 & 1 \\
\hline NP8 & Orillia & 2 & 1 & 1 & 0 & 4 \\
\hline NP9 & Orillia & 3 & 2 & 1 & 0 & 6 \\
\hline BB1 & Georgina Island & 0 & 3 & 0 & 0 & 3 \\
\hline BB2 & Georgina Island & 0 & 0 & 1 & 0 & 1 \\
\hline BB3 & Georgina Island & 1 & 0 & 0 & 0 & 1 \\
\hline BB4 & Georgina Island & 0 & 0 & 0 & 0 & 0 \\
\hline BB5 & Orillia & 0 & 0 & 2 & 0 & 2 \\
\hline BB6 & Orillia & 0 & 0 & 0 & 0 & 0 \\
\hline BB7 & Orillia & 2 & 2 & 5 & 0 & 9 \\
\hline BB8 & Orillia & 0 & 0 & 0 & 0 & 0 \\
\hline BB9 & Orillia & 3 & 0 & 1 & 0 & 4 \\
\hline WS1 & Georgina Island & 0 & 0 & 0 & 0 & 0 \\
\hline WS2 & Georgina Island & 0 & 4 & 0 & 0 & 4 \\
\hline WS3 & Georgina Island & 0 & 1 & 0 & 0 & 1 \\
\hline WS4 & Orillia & 4 & 1 & 1 & 0 & 6 \\
\hline WS5 & Orillia & 2 & 0 & 11 & 1 & 14 \\
\hline WS6 & Orillia & 2 & 1 & 0 & 0 & 3 \\
\hline WS7 & Orillia & 1 & 0 & 0 & 0 & 1 \\
\hline WS8 & Orillia & 3 & 3 & 1 & 1 & 8 \\
\hline LW1 & Georgina Island & 2 & 0 & 1 & 0 & 3 \\
\hline LW2 & Georgina Island & 0 & 4 & 0 & 1 & 5 \\
\hline LW3 & Georgina Island & 4 & 1 & 1 & 0 & 6 \\
\hline LW4 & Georgina Island & 1 & 2 & 3 & 0 & 6 \\
\hline LW5 & Georgina Island & 0 & 4 & 0 & 0 & 4 \\
\hline LW6 & Kempenfelt Bay & 2 & 1 & 0 & 0 & 3 \\
\hline LW7 & Kempenfelt Bay & 0 & 1 & 1 & 0 & 2 \\
\hline LW8 & Kempenfelt Bay & 0 & 0 & 1 & 0 & 1 \\
\hline LW9 & Kempenfelt Bay & 0 & 0 & 3 & 0 & 3 \\
\hline LW10 & Kempenfelt Bay & 0 & 1 & 0 & 0 & 1 \\
\hline & Total & 105 & 92 & 78 & 9 & 284 \\
\hline & & & & & \\
\hline
\end{tabular}


Table S7. Summary of suspected microplastics in liver of fish from Lake Simcoe, after blank subtraction. Suspected microplastics in both the $>125 \mu \mathrm{m}$ and $63 \mu \mathrm{m}$ size fractions are included and there is no liver data for one Smallmouth Bass (SB3), three Largemouth Bass (LB1,LB3,

LB5), and all White Sucker (WS1-8).

\begin{tabular}{|c|c|c|c|c|c|c|}
\hline Sample & Site & Fiber & Fragment & Film & Foam & Total \\
\hline SB1 & Georgina Island & 1 & 0 & 0 & 0 & 1 \\
\hline SB2 & Georgina Island & 0 & 0 & 2 & 0 & 2 \\
\hline SB3 & Georgina Island & $N A$ & $N A$ & $N A$ & $N A$ & $N A$ \\
\hline SB4 & Georgina Island & 0 & 0 & 5 & 0 & 5 \\
\hline SB5 & Georgina Island & 0 & 0 & 2 & 0 & 2 \\
\hline SB6 & Georgina Island & 0 & 0 & 1 & 0 & 1 \\
\hline SB7 & Orillia & 0 & 0 & 1 & 0 & 1 \\
\hline LB1 & Georgina Island & $N A$ & $N A$ & $N A$ & $N A$ & $N A$ \\
\hline LB2 & Georgina Island & 2 & 0 & 0 & 0 & 2 \\
\hline LB3 & Georgina Island & $N A$ & $N A$ & $N A$ & $N A$ & $N A$ \\
\hline LB4 & Georgina Island & 1 & 0 & 1 & 0 & 2 \\
\hline LB5 & Georgina Island & $N A$ & $N A$ & $N A$ & $N A$ & $N A$ \\
\hline LB6 & Orillia & 3 & 0 & 0 & 0 & 3 \\
\hline LB7 & Orillia & 0 & 0 & 0 & 0 & 0 \\
\hline LB8 & Orillia & 0 & 0 & 0 & 0 & 0 \\
\hline LB9 & Orillia & 0 & 0 & 0 & 0 & 0 \\
\hline LB10 & Orillia & 0 & 0 & 1 & 0 & 1 \\
\hline YP1 & Georgina Island & 0 & 0 & 0 & 0 & 0 \\
\hline YP2 & Georgina Island & 0 & 0 & 0 & 0 & 0 \\
\hline YP3 & Georgina Island & 0 & 0 & 0 & 0 & 0 \\
\hline YP4 & Georgina Island & 0 & 0 & 2 & 0 & 2 \\
\hline YP5 & Georgina Island & 0 & 0 & 0 & 0 & 0 \\
\hline YP6 & Georgina Island & 2 & 0 & 2 & 0 & 4 \\
\hline YP7 & Georgina Island & 1 & 0 & 1 & 0 & 2 \\
\hline YP8 & Georgina Island & 0 & 0 & 0 & 0 & 0 \\
\hline YP9 & Georgina Island & 0 & 0 & 0 & 0 & 0 \\
\hline YP10 & Georgina Island & 0 & 0 & 0 & 0 & 0 \\
\hline YP11 & Kempenfelt Bay & 1 & 0 & 0 & 0 & 1 \\
\hline YP12 & Kempenfelt Bay & 0 & 0 & 0 & 0 & 0 \\
\hline YP13 & Kempenfelt Bay & 0 & 0 & 2 & 0 & 2 \\
\hline YP14 & Kempenfelt Bay & 1 & 0 & 0 & 0 & 1 \\
\hline YP15 & Kempenfelt Bay & 0 & 0 & 0 & 0 & 0 \\
\hline YP16 & Kempenfelt Bay & 0 & 0 & 0 & 0 & 0 \\
\hline NP1 & Georgina Island & 1 & 0 & 2 & 0 & 3 \\
\hline NP2 & Georgina Island & 3 & 0 & 0 & 0 & 3 \\
\hline NP3 & Georgina Island & 4 & 0 & 2 & 0 & 6 \\
\hline NP4 & Georgina Island & 6 & 0 & 3 & 0 & 9 \\
\hline NP5 & Georgina Island & 1 & 0 & 2 & 0 & 3 \\
\hline
\end{tabular}




\begin{tabular}{|l|l|l|l|l|l|l|}
\hline NP6 & Orillia & 1 & 1 & 0 & 0 & 2 \\
\hline NP7 & Orillia & 0 & 0 & 0 & 0 & 0 \\
\hline NP8 & Orillia & 0 & 0 & 1 & 0 & 1 \\
\hline NP9 & Orillia & 2 & 0 & 0 & 0 & 2 \\
\hline BB1 & Georgina Island & 0 & 0 & 0 & 1 & 1 \\
\hline BB2 & Georgina Island & 2 & 0 & 1 & 0 & 3 \\
\hline BB3 & Georgina Island & 0 & 0 & 1 & 0 & 1 \\
\hline BB4 & Georgina Island & 0 & 0 & 1 & 0 & 1 \\
\hline BB5 & Orillia & 8 & 0 & 0 & 0 & 8 \\
\hline BB6 & Orillia & 1 & 0 & 0 & 0 & 1 \\
\hline BB7 & Orillia & 2 & 0 & 0 & 0 & 2 \\
\hline BB8 & Orillia & 0 & 0 & 0 & 0 & 0 \\
\hline BB9 & Orillia & 0 & 1 & 0 & 0 & 1 \\
\hline WS1 & Georgina Island & $N A$ & $N A$ & $N A$ & $N A$ & $N A$ \\
\hline WS2 & Georgina Island & $N A$ & $N A$ & $N A$ & $N A$ & $N A$ \\
\hline WS3 & Georgina Island & $N A$ & $N A$ & $N A$ & $N A$ & $N A$ \\
\hline WS4 & Orillia & $N A$ & $N A$ & $N A$ & $N A$ & $N A$ \\
\hline WS5 & Orillia & $N A$ & $N A$ & $N A$ & $N A$ & $N A$ \\
\hline WS6 & Orillia & $N A$ & $N A$ & $N A$ & $N A$ & $N A$ \\
\hline WS7 & Orillia & $N A$ & $N A$ & $N A$ & $N A$ & $N A$ \\
\hline WS8 & Orillia & $N A$ & $N A$ & $N A$ & $N A$ & $N A$ \\
\hline LW1 & Georgina Island & 2 & 1 & 2 & 0 & 5 \\
\hline LW2 & Georgina Island & 0 & 0 & 0 & 0 & 0 \\
\hline LW3 & Georgina Island & 0 & 0 & 0 & 0 & 0 \\
\hline LW4 & Georgina Island & 0 & 0 & 0 & 0 & 0 \\
\hline LW5 & Georgina Island & 0 & 0 & 0 & 0 & 0 \\
\hline LW6 & Kempenfelt Bay & 0 & 0 & 0 & 0 & 0 \\
\hline LW7 & Kempenfelt Bay & 1 & 0 & 0 & 0 & 1 \\
\hline LW8 & Kempenfelt Bay & 1 & 0 & 0 & 0 & 1 \\
\hline LW9 & Kempenfelt Bay & 0 & 0 & 0 & 0 & 0 \\
\hline LW10 & Kempenfelt Bay & 0 & 0 & 1 & 0 & 1 \\
\hline & Total & 47 & 3 & 36 & 1 & 87 \\
\hline & & & & & \\
\hline
\end{tabular}


Table S8. PERMANOVA table for nMDS analyses using Euclidean distance. Permutations $=999$.

\begin{tabular}{|c|c|c|c|c|c|c|}
\hline Particle Identity & df & Sum Sq. & Mean Sq. & F model & $\mathbf{R}^{2}$ & $p$-value \\
\hline \multicolumn{7}{|l|}{ a) Morphology } \\
\hline i. Sample type & 1 & 13.2 & 13.25 & 0.31 & 0.0021 & 0.6 \\
\hline Residuals & 155 & 6528.4 & 42.12 & & 0.99 & \\
\hline Total & 156 & 6541.7 & & & 1.00 & \\
\hline ii. Tissue & 2 & 1961.2 & 980.60 & 37.84 & 0.29 & $0.001 * *$ \\
\hline Residuals & 187 & 4845.9 & 25.91 & & 0.71 & \\
\hline Total & 189 & 6807.1 & & & 1.00 & \\
\hline \multicolumn{7}{|l|}{ b) Chemical ID } \\
\hline i. Sample type & 1 & 30.7 & 30.65 & 10.44 & 0.072 & $0.001 * *$ \\
\hline Residuals & 134 & 393.2 & 2.93 & & 0.93 & \\
\hline Total & 135 & 423.9 & & & 1.00 & \\
\hline ii. Tissue & 2 & 26.2 & 13.12 & 7.25 & 0.088 & $0.001 * *$ \\
\hline Residuals & 150 & 272.2 & 1.81 & & 0.91 & \\
\hline Total & 152 & 297.5 & & & 1.00 & \\
\hline iii. Size fraction & 1 & 25.4 & 25.36 & 14.08 & 0.085 & $0.001 * *$ \\
\hline Residuals & 151 & 272.1 & 1.80 & & 0.91 & \\
\hline Total & 152 & 297.5 & & & 1.00 & \\
\hline
\end{tabular}

** indicates significance. 
Table S9. Results of Kruskal-Wallis and Mann Whitney U tests, comparing differences in suspected microplastic abundance among species and habitat.

\begin{tabular}{llll}
\hline Test & & df & p-value \\
\hline a) Kruskal-Wallis & $\mathrm{x}^{2}$ & & \\
\hline Total particle abundance $\sim$ species & 30.80 & 6 & $<0.001^{* *}$ \\
Fillet + liver particle abundance $\sim$ species & 20.60 & 6 & $0.0022^{* *}$ \\
& & & \\
b) Mann Whitney & W & & 0.42 \\
\hline Total particle abundance $\sim$ habitat & 634 & & 0.82 \\
Fillet + liver particle abundance $\sim$ habitat & 548 & & \\
\hline
\end{tabular}

** indicates significance. 


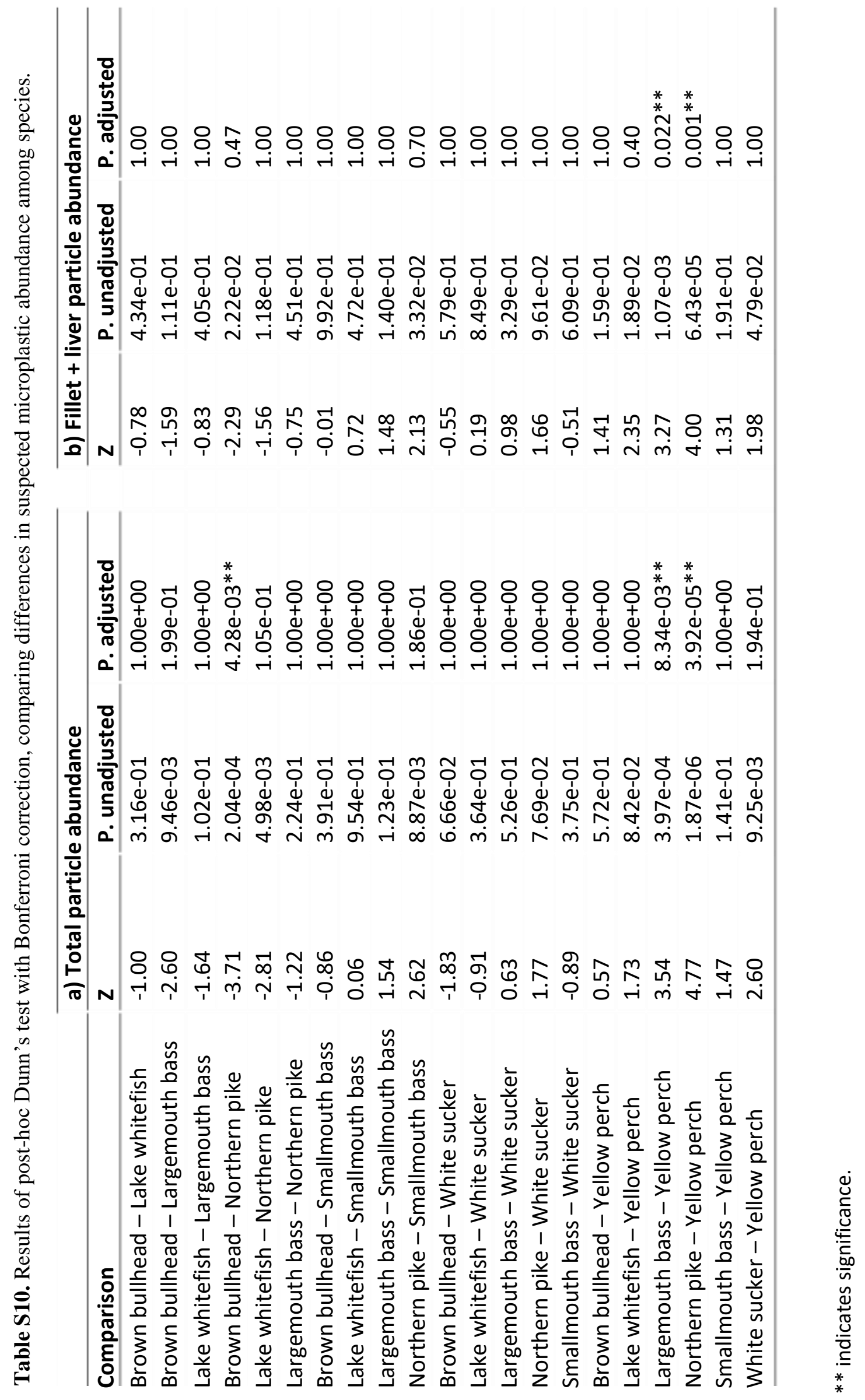




\section{References}

(1) Munno, K.; Helm, P. A.; Jackson, D. A.; Rochman, C.; Sims, A. Impacts of Temperature and Selected Chemical Digestion Methods on Microplastic Particles. Environ. Toxicol. Chem. 2018, 37 (1), 91-98. https://doi.org/10.1002/etc.3935.

(2) Munno, K.; De Frond, H.; O’Donnell, B.; Rochman, C. M. Increasing the Accessibility for Characterizing Microplastics: Introducing New Application-Based and Spectral Libraries of Plastic Particles (SLoPP and SLoPP-E). Anal. Chem. 2020, 92 (3), 2443-2451. https://doi.org/10.1021/acs.analchem.9b03626.

(3) Froese, R.; Pauly, D. FishBase 2000: Conceptrs, Design and Data Sources. World Wide Web electronic publication 2000.

(4) Horton, A. A.; Jürgens, M. D.; Lahive, E.; van Bodegom, P. M.; Vijver, M. G. The Influence of Exposure and Physiology on Microplastic Ingestion by the Freshwater Fish Rutilus Rutilus (Roach) in the River Thames, UK. Environ. Pollut. 2018, 236, 188-194. https://doi.org/10.1016/j.envpol.2018.01.044.

(5) Jabeen, K.; Su, L.; Li, J.; Yang, D.; Tong, C.; Mu, J.; Shi, H. Microplastics and Mesoplastics in Fish from Coastal and Fresh Waters of China. Environ. Pollut. 2017, 221, 141-149. https://doi.org/10.1016/j.envpol.2016.11.055.

(6) Campbell, S. H.; Williamson, P. R.; Hall, B. D. Microplastics in the Gastrointestinal Tracts of Fish and the Water from an Urban Prairie Creek. FACETS 2017, 2 (1), 395-409. https://doi.org/10.1139/facets-2017-0008.

(7) Lusher, A.; McHugh, M.; Thompson, R. C. Occurrence of Microplastics in the Gastrointestinal Tract of Pelagic and Demersal Fish from the English Channel. Mar. Pollut. Bull. 2013, 67 (1-2), 94-99. https://doi.org/10.1016/j.marpolbul.2012.11.028.

(8) McGoran, A. R.; Clark, P. F.; Morritt, D. Presence of Microplastic in the Digestive Tracts of European Flounder, Platichthys Flesus, and European Smelt, Osmerus Eperlanus, from the River Thames. Environ. Pollut. 2017, 220, 744-751. https://doi.org/10.1016/j.envpol.2016.09.078.

(9) Murphy, F.; Russell, M.; Ewins, C.; Quinn, B. The Uptake of Macroplastic \& Microplastic by Demersal \& Pelagic Fish in the Northeast Atlantic around Scotland. Mar. Pollut. Bull. 2017, 122 (1), 353-359. https://doi.org/10.1016/j.marpolbul.2017.06.073.

(10) Felismino, M. E. L.; Helm, P. A.; Rochman, C. M. Microplastic and Other Anthropogenic Microparticles in Water and Sediments of Lake Simcoe. J. Gt. Lakes Res. 2020. https://doi.org/10.1016/j.jglr.2020.10.007.

(11) Koslow, J. A. Energetic and Life-History Patterns of Deep-Sea Benthic, Benthopelagic and Seamount-Associated Fish. J. Fish Biol. 1996, 49 (sa), 54-74. https://doi.org/10.1111/j.1095-8649.1996.tb06067.x.

(12) Critchell, K.; Hoogenboom, M. O. Effects of Microplastic Exposure on the Body Condition and Behaviour of Planktivorous Reef Fish (Acanthochromis Polyacanthus). PLoS ONE 2018, 13 (3). https://doi.org/10.1371/journal.pone.0193308. 
(13) Foley, C. J.; Feiner, Z. S.; Malinich, T. D.; Höök, T. O. A Meta-Analysis of the Effects of Exposure to Microplastics on Fish and Aquatic Invertebrates. Sci. Total Environ. 2018, 631-632, 550-559. https://doi.org/10.1016/j.scitotenv.2018.03.046.

(14) Jeong, C.-B.; Kang, H.-M.; Lee, M.-C.; Kim, D.-H.; Han, J.; Hwang, D.-S.; Souissi, S.; Lee, S.-J.; Shin, K.-H.; Park, H. G.; Lee, J.-S. Adverse Effects of Microplastics and Oxidative Stress-Induced MAPK/Nrf2 Pathway-Mediated Defense Mechanisms in the Marine Copepod Paracyclopina Nana. Sci. Rep. 2017, 7 (1), 41323. https://doi.org/10.1038/srep41323.

(15) Lu, Y.; Zhang, Y.; Deng, Y.; Jiang, W.; Zhao, Y.; Geng, J.; Ding, L.; Ren, H. Uptake and Accumulation of Polystyrene Microplastics in Zebrafish (Danio Rerio) and Toxic Effects in Liver. Environ. Sci. Technol. 2016, 50 (7), 4054-4060. https://doi.org/10.1021/acs.est.6b00183.

(16) Magni, S.; Gagné, F.; André, C.; Della Torre, C.; Auclair, J.; Hanana, H.; Parenti, C. C.; Bonasoro, F.; Binelli, A. Evaluation of Uptake and Chronic Toxicity of Virgin Polystyrene Microbeads in Freshwater Zebra Mussel Dreissena Polymorpha (Mollusca: Bivalvia). Sci. Total Environ. 2018, 631-632, 778-788. https://doi.org/10.1016/j.scitotenv.2018.03.075.

(17) Rochman, C. M.; Kurobe, T.; Flores, I.; Teh, S. J. Early Warning Signs of Endocrine Disruption in Adult Fish from the Ingestion of Polyethylene with and without Sorbed Chemical Pollutants from the Marine Environment. Sci. Total Environ. 2014, 493, 656661. https://doi.org/10.1016/j.scitotenv.2014.06.051.

(18) Welden, N. A. C.; Cowie, P. R. Long-Term Microplastic Retention Causes Reduced Body Condition in the Langoustine, Nephrops Norvegicus. Environ. Pollut. 2016, 218, 895-900. https://doi.org/10.1016/j.envpol.2016.08.020.

(19) Sussarellu, R.; Suquet, M.; Thomas, Y.; Lambert, C.; Fabioux, C.; Pernet, M. E. J.; Le Goïc, N.; Quillien, V.; Mingant, C.; Epelboin, Y.; Corporeau, C.; Guyomarch, J.; Robbens, J.; Paul-Pont, I.; Soudant, P.; Huvet, A. Oyster Reproduction Is Affected by Exposure to Polystyrene Microplastics. Proc. Natl. Acad. Sci. 2016, 113 (9), 2430-2435. https://doi.org/10.1073/pnas.1519019113.

(20) Barboza, L. G. A.; Vieira, L. R.; Guilhermino, L. Single and Combined Effects of Microplastics and Mercury on Juveniles of the European Seabass (Dicentrarchus Labrax): Changes in Behavioural Responses and Reduction of Swimming Velocity and Resistance Time. Environ. Pollut. 2018, 236, 1014-1019. https://doi.org/10.1016/j.envpol.2017.12.082.

(21) Barboza, L. G. A.; Dick Vethaak, A.; Lavorante, B. R. B. O.; Lundebye, A.-K.; Guilhermino, L. Marine Microplastic Debris: An Emerging Issue for Food Security, Food Safety and Human Health. Mar. Pollut. Bull. 2018, 133, 336-348. https://doi.org/10.1016/j.marpolbul.2018.05.047. 